\title{
請 演
}

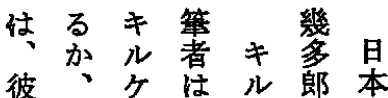

の亡

思た 1放 和田お

想そルが 辺け

ののの权ル元る

中中著提ののセ

心加作唱特 I

に $ら$ し 異合

あキほてなをン

るルとき思考:

青午岕た想えた

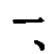

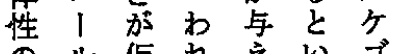

のル仮れえい゙

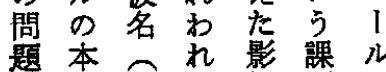

加来偽㤎響題の

らの名、をを思

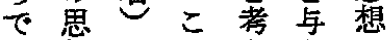

あ想でのええの

るを書視るら影

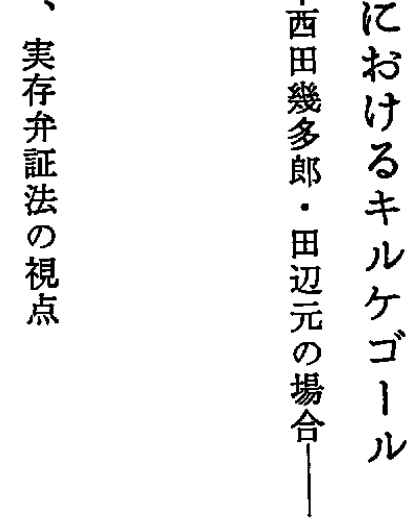

の点盛机部

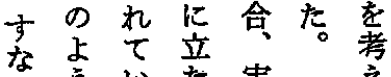

わういた塞え

ち、に るざ

主抽そ党法部

体出机なと文

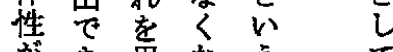

架き思なうう

理加傿点

で、究理㤎者

ると少瓷問派

$\left.\right|_{\text {西本 }} ^{\text {日 }}$

田お

幾付

郎る

田儿

元ケ

の ゴ

場 1

ル

と閣料三題

以題乞つ学

う加市り の

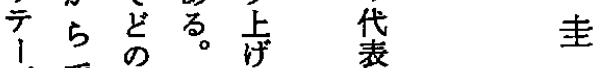

ゼでよまる

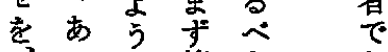

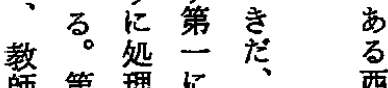

小

治

淿第理に守要 


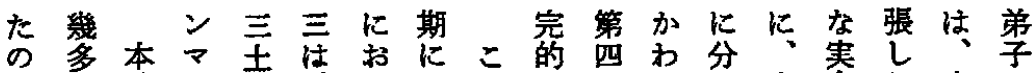

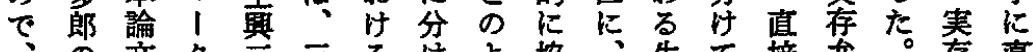
の齐ク豆三る订よ協、生て接弁。存直 こキ方語加采上るう実涯考的証こ伝接 こル扱原ら清田こなし存のえに法の達的 でク は ヨ゙のに西紹、が味口証究見正視う伝 、1注界芥金ででて法公確点な間達

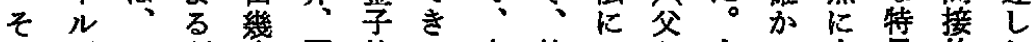
れ理こ研多 目筑る。塞第占交すつ立異的た

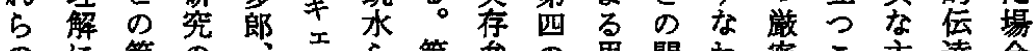

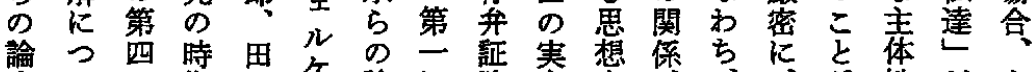

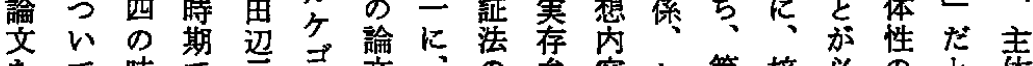

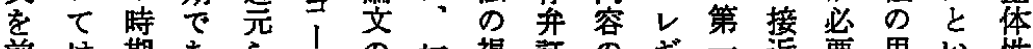
前恃期あのらルの初視証のギ二近要思い性 提 筆のる。の、選時期点法主!は守た想いは 者代宗隹分す立対的体キこ考伝洼

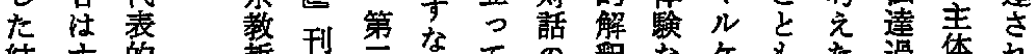

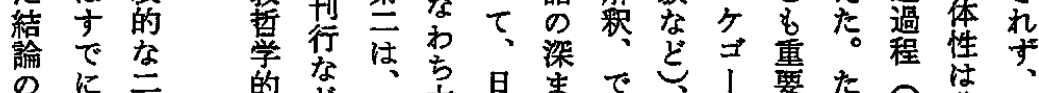

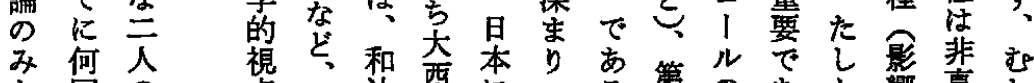

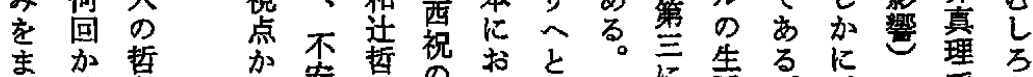

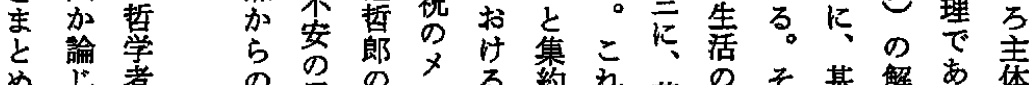

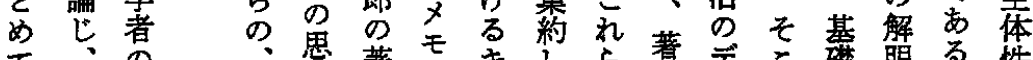

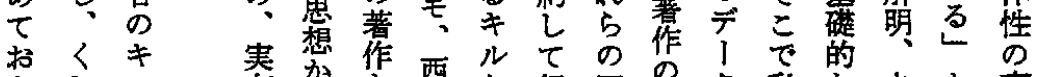

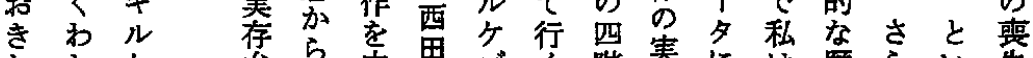

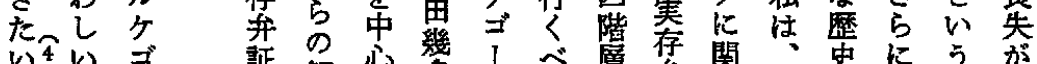

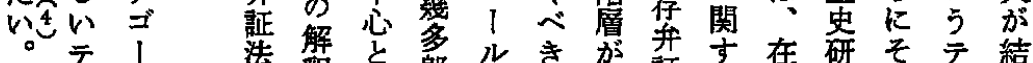
そキル法彩と郎受き排証方在研そテ結

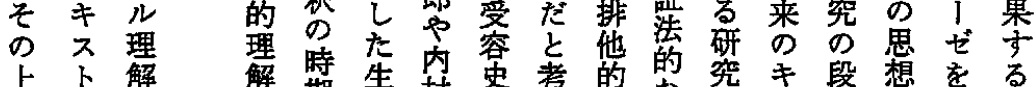

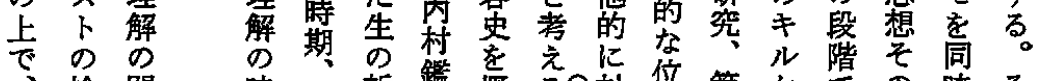

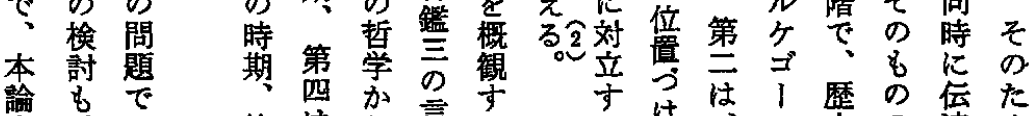

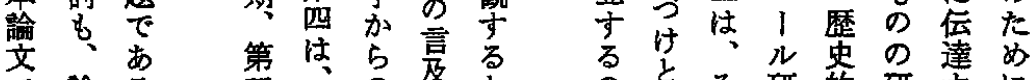

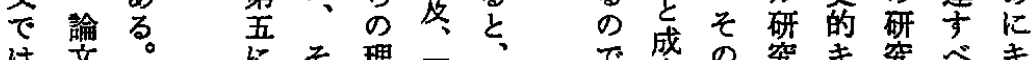

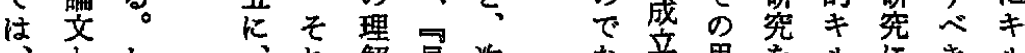

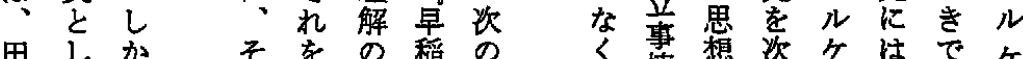
田しかしく秀想次尔はでケ

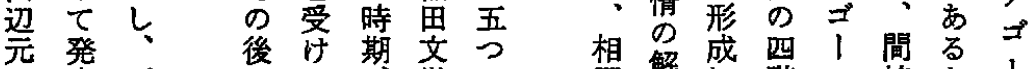

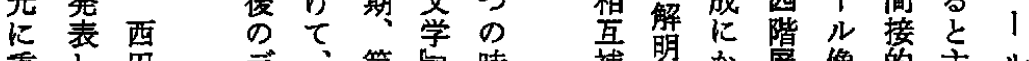

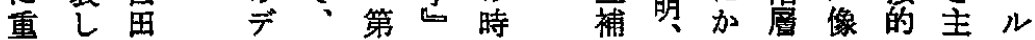




\section{講 演}

が 前九

き半四第瞬の叹昜第反教西方明西

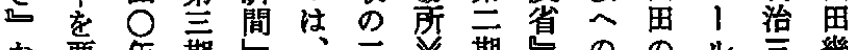

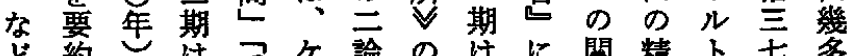

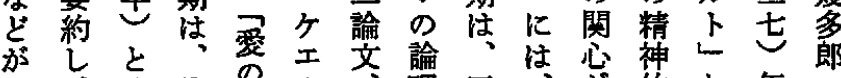

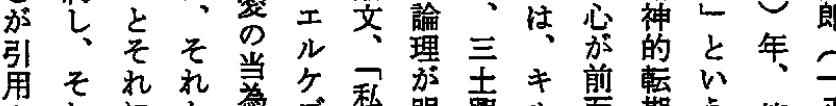

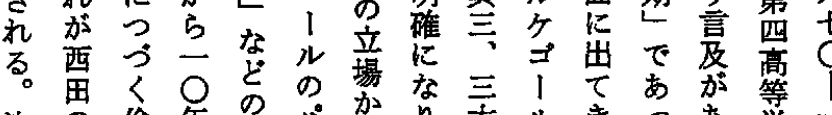

決 の 倫 年

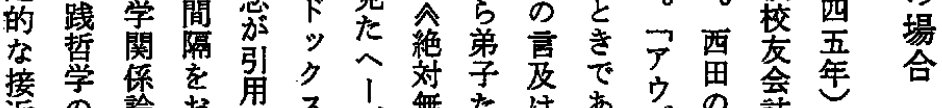

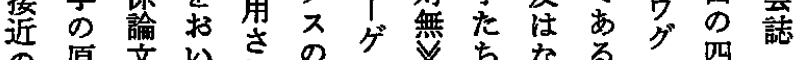

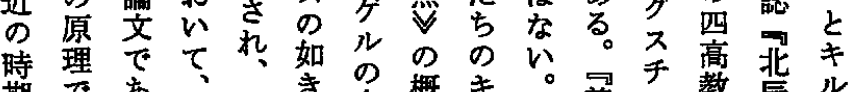

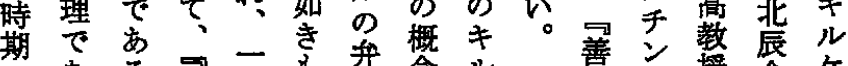

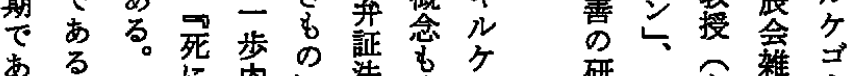

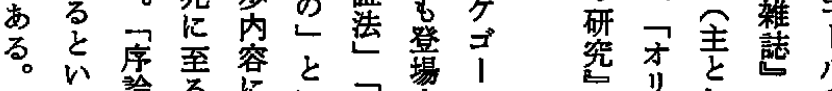

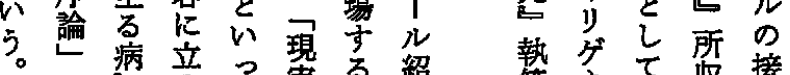

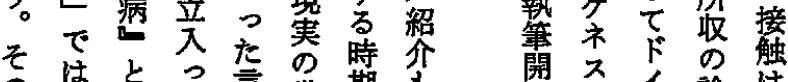

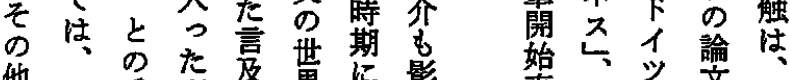

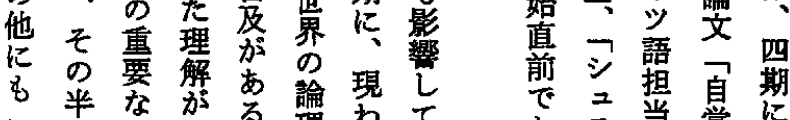

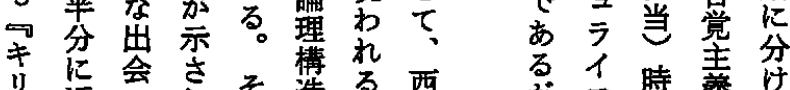

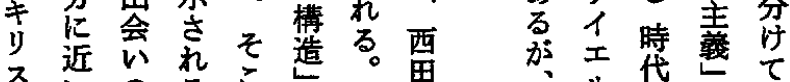

トいの る

教四で時無学善 ッあああた

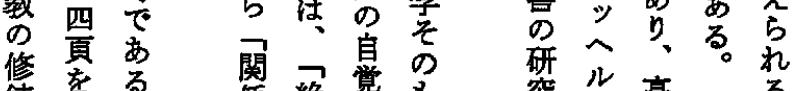

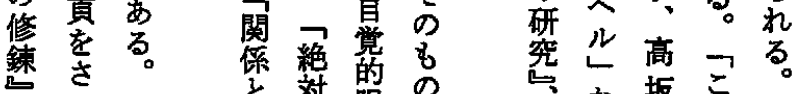

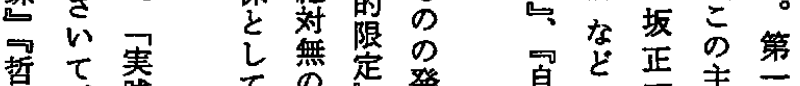

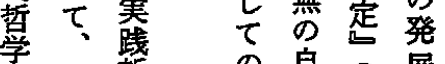

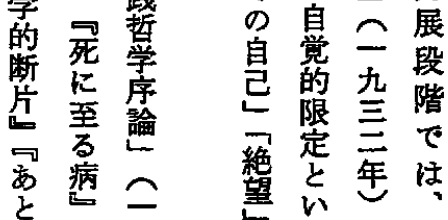

䚁令顕 義 期

に觉の む菚期

お言以先

计名 引鋒一

る 直京

観り、に心 四 


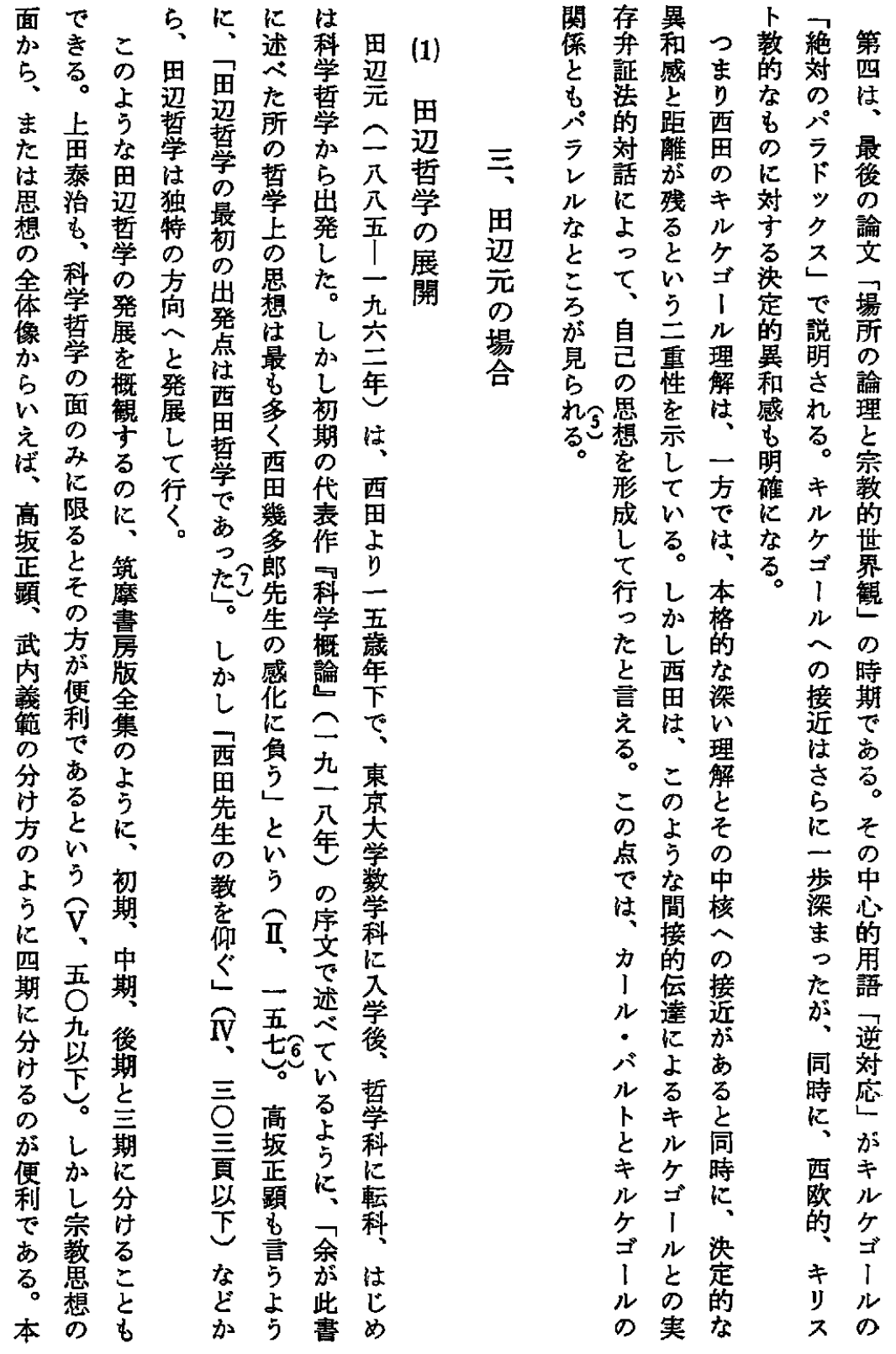




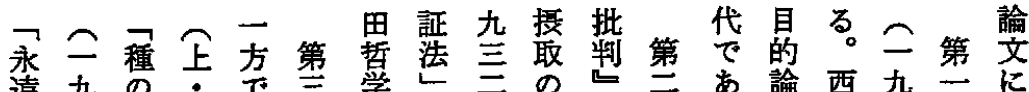

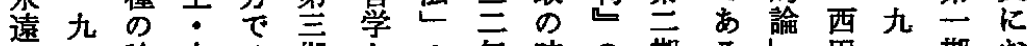
-三論中注期との年時の期るし田一期校 糜入理・宗は語期研はこ气の八はい 更年の下教:線㤎所で究、三元可年、て

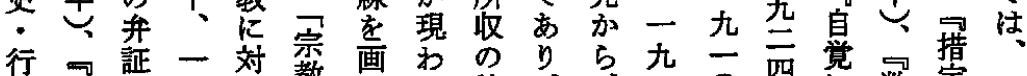

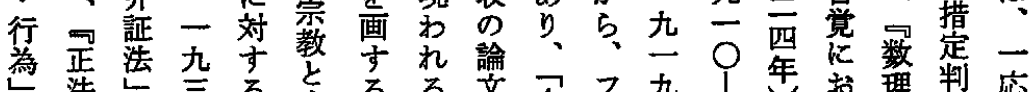

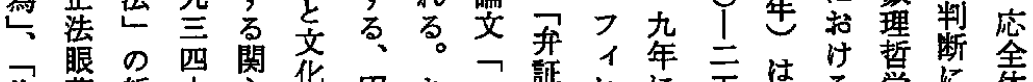

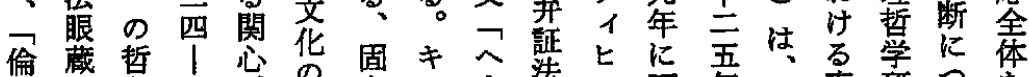
理の学三方間有ル法テ西年直研つを

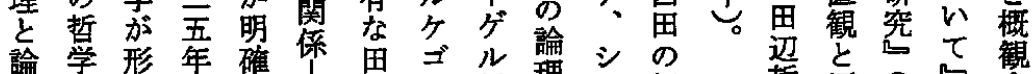

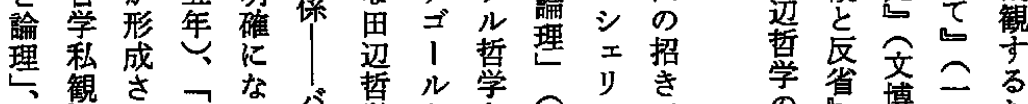

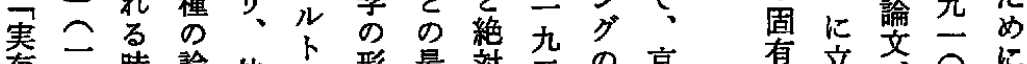

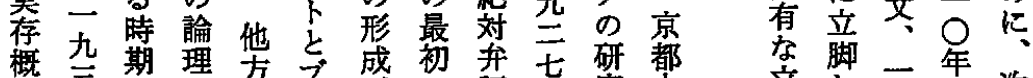

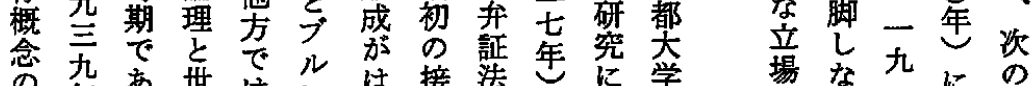

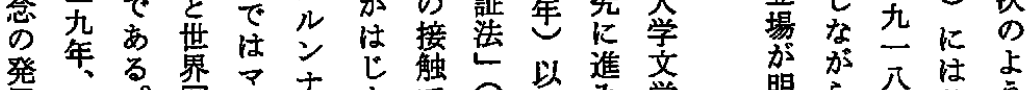

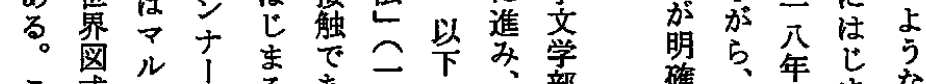

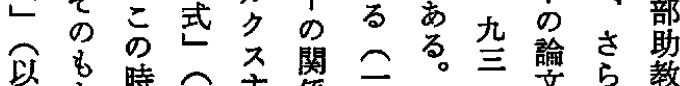
上時乞主蔺二。三文

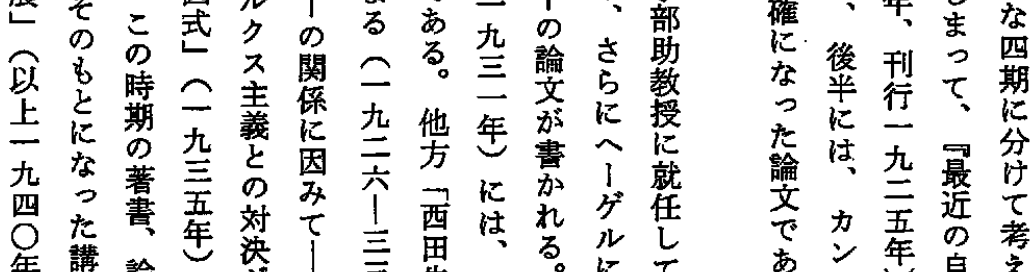

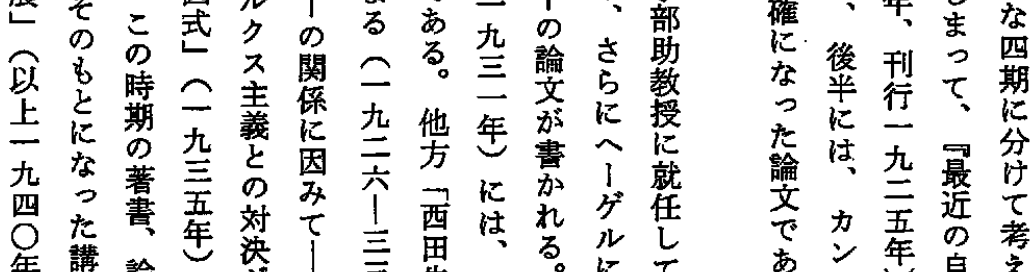

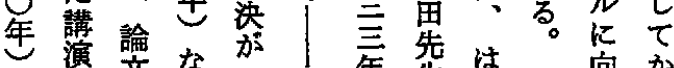

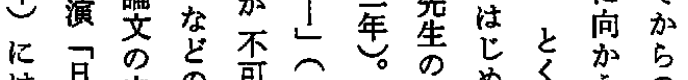

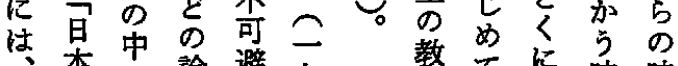

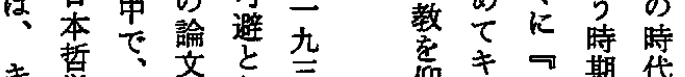

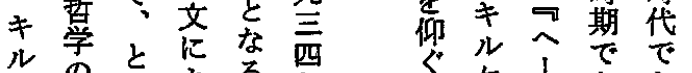

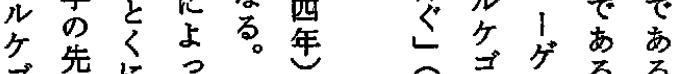

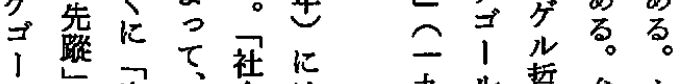

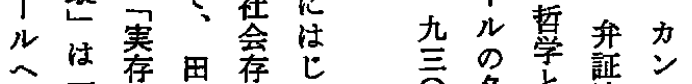

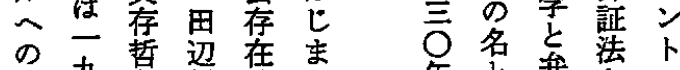

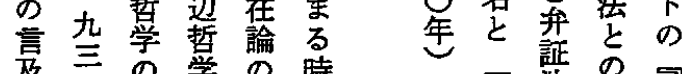
是方の学の時 分年限固論期実法対判 現年界有理で斯・存決断 わ、是里

西 弁二と力

に、磼、年末な

な华行て 期

た

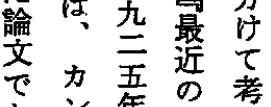

あ六年自え る。研な然行 表究䓘样行

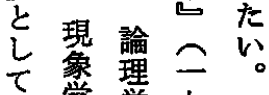
重学掌旮 丠缹科吾 学简学等 学 繁 部つ科 講力時 学 講 光期 概 のトで論 時のあ的 


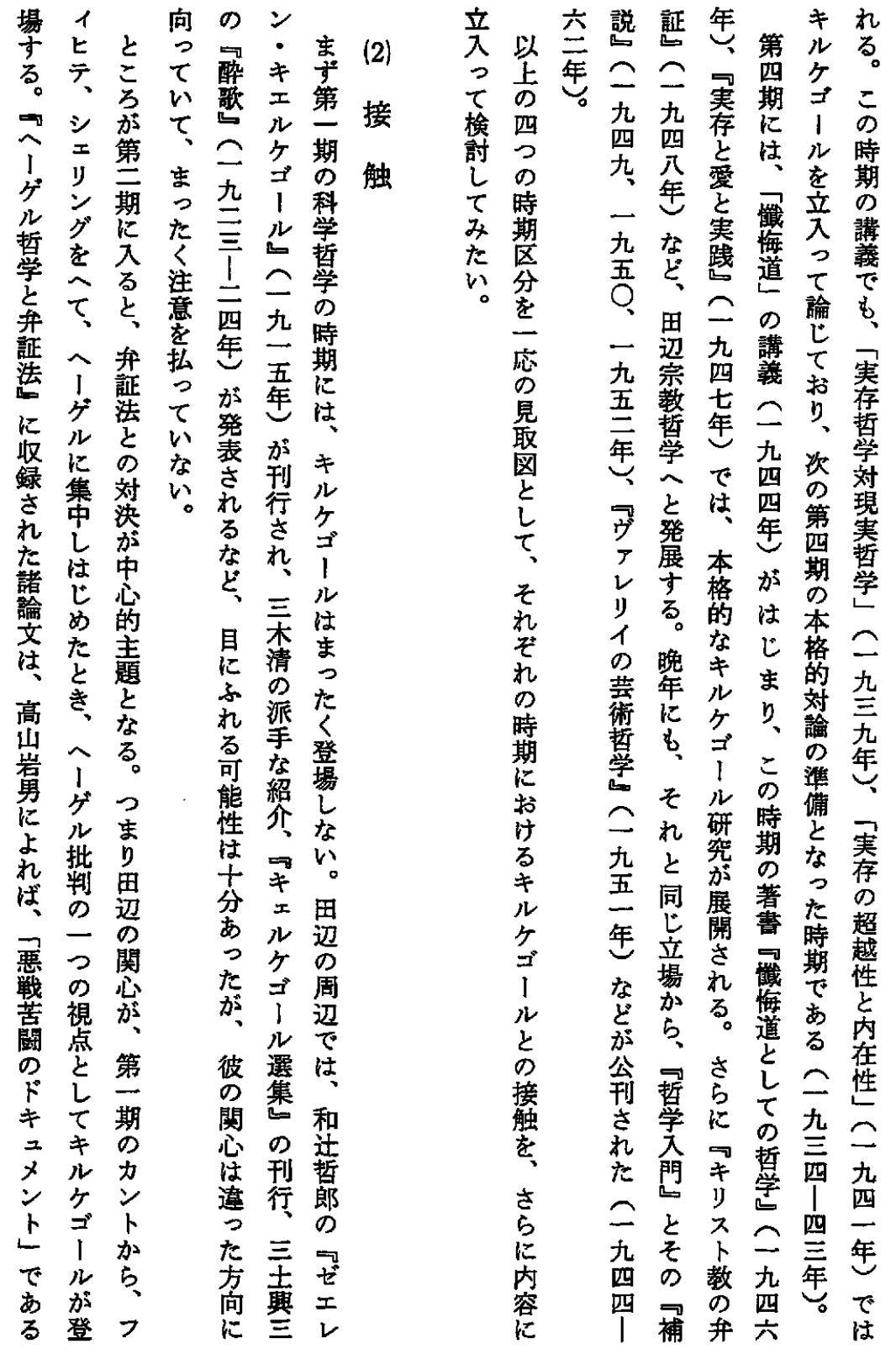


重 関

な課心田

る。題㤎辺

そな確学 接

のっなの

対七形 展 近

決きを開

のたをの

思こ 第

想とて

的方 現 期

拠あわに

㫹势尚

と西方

し田そで

て、閇背述

宗の後

教严にた

へ杰は

の 清 施

関照に

忍坂贷バ

深潤思

ま ら 想卜

るに動 文

まるかル

た

そルマナ

れクル।

怔スクの

西主 ス 論

田義主 争

のの義を

キ論と紹

ル議本仝

ケ方格守

$\exists$ 盛的る

1んなな

ルに対

々な決、

のつ方宗

接た避教

触時们

の 期 ら 対

第它れ守

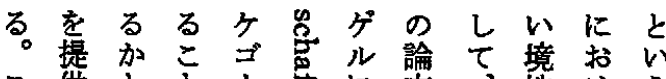
こ供とと1要に文、地けら

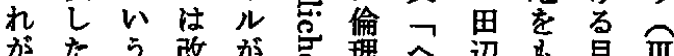

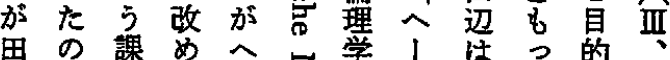

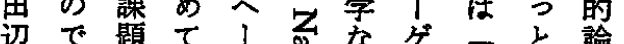

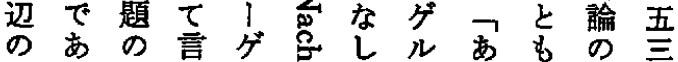
キる。市ル思哲る端視三 ルこ、で純繁学かに市

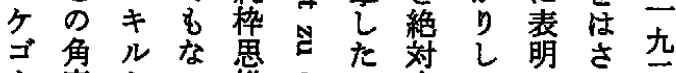
I度ヶい惟号の茾へしん三

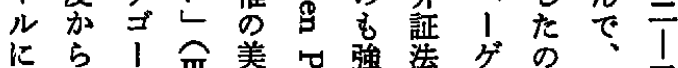

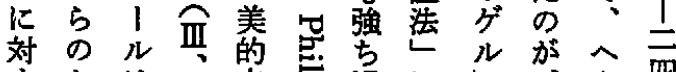

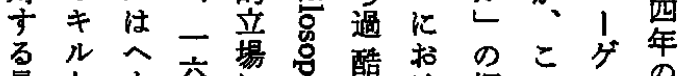

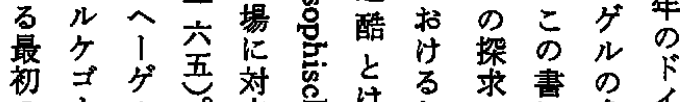

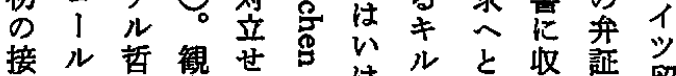

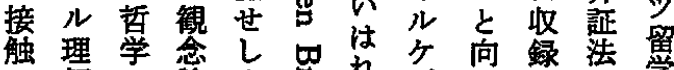

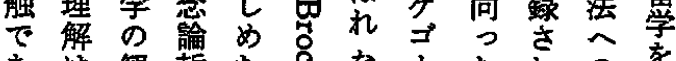

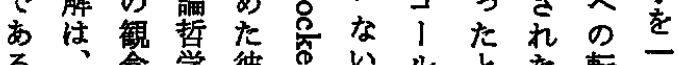

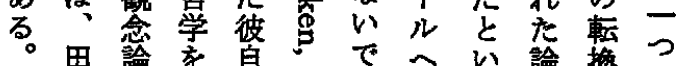

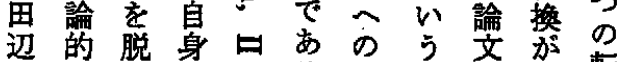

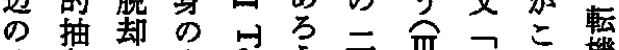

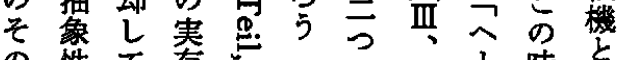

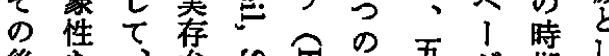

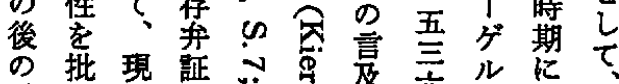

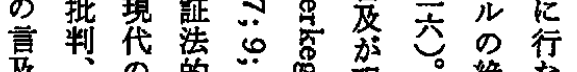

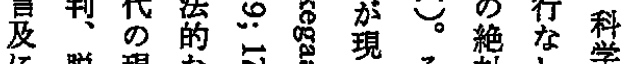

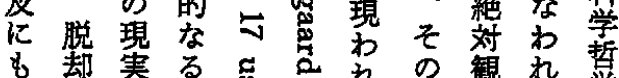

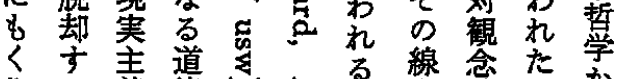

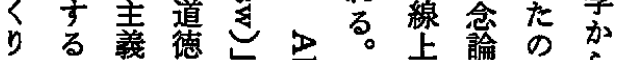

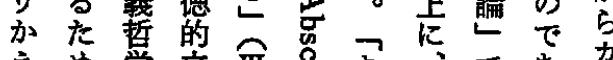

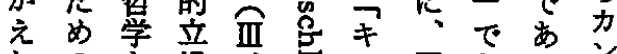

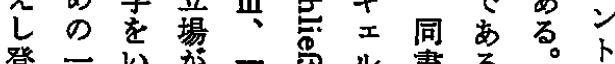

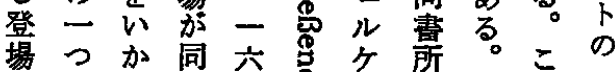

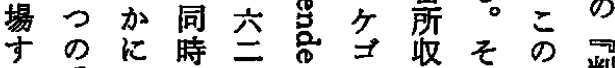

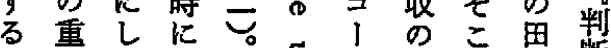

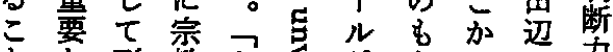

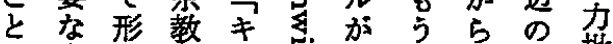

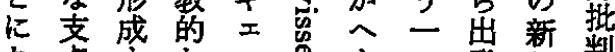
な点子なル思人っ発等判 


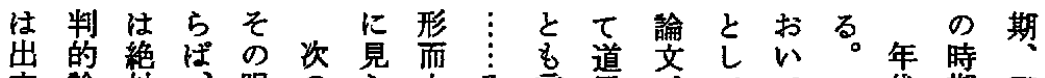

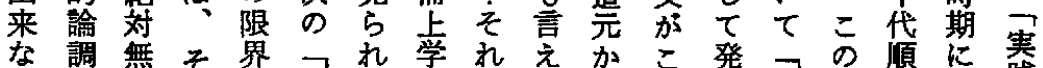

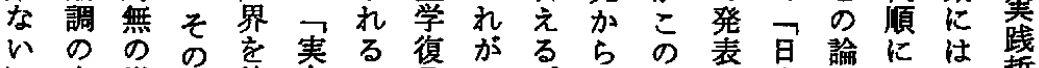

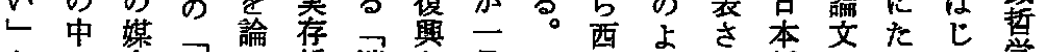
とで芥実し哲消と見こ田う机哲の学学

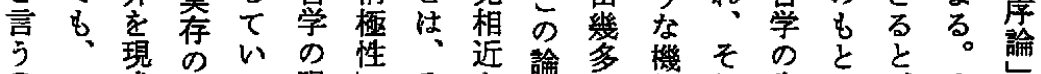

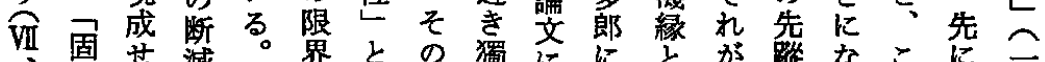

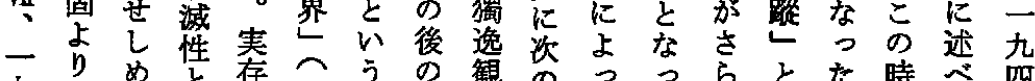

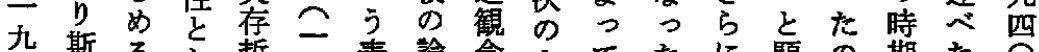
过斯るか哲九表論愈よてたに題の期たつ

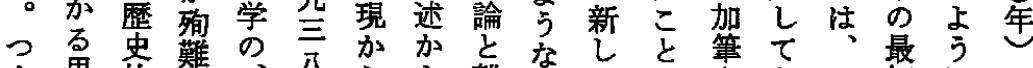

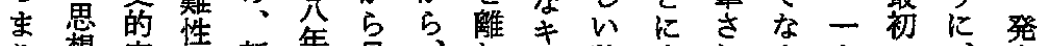
り想実性新年自、杂装喜机さ九の心、表

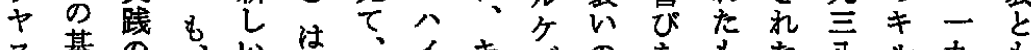

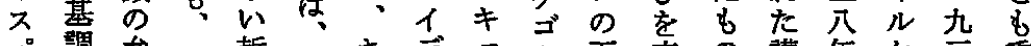
パ調弁な珤ヤキデェ

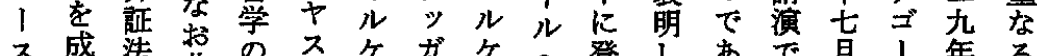
ス成法翡のスケガケへ登しあで月、年る 八す的城構

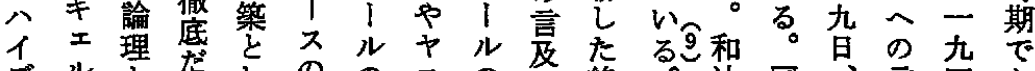
デルなだしののスの范絶す迁同、言四あ

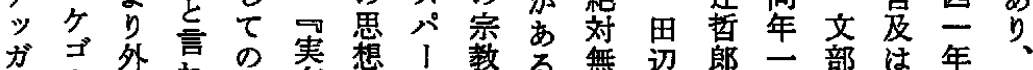
ガゴ外言の実想 I 教る無辺郎二部は年 にル成な意哲に親哲。ののの○省、の田

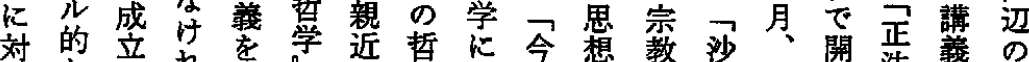

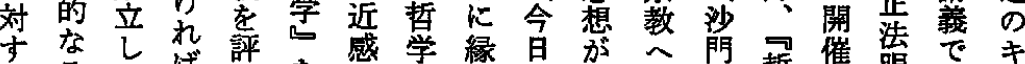

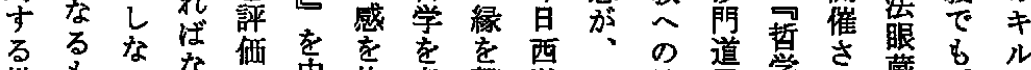

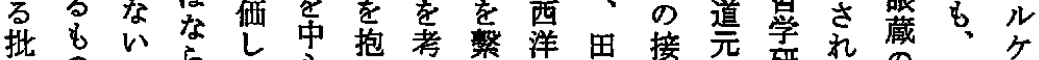

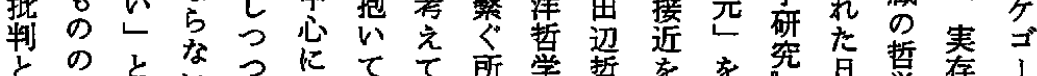

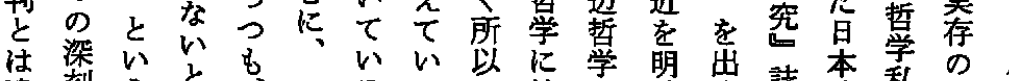

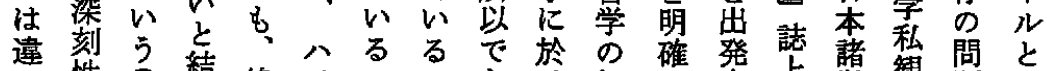

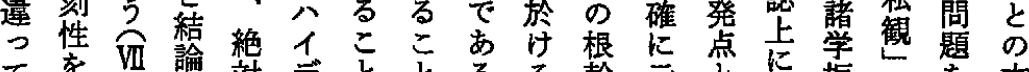
てを、論詨

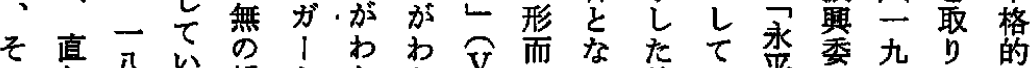
の方气い哲

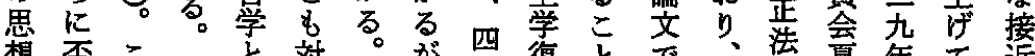
想歪こ行文対。が分復とで、眼夏年て近

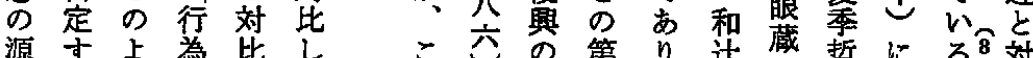

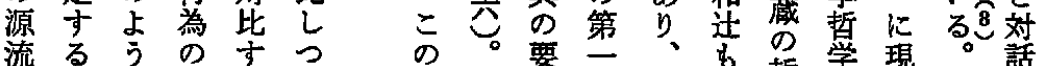

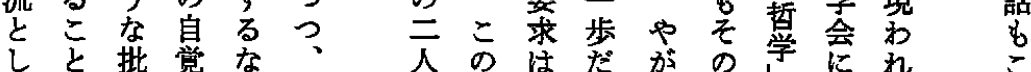


く初るのルる元理実す層ういてしをて

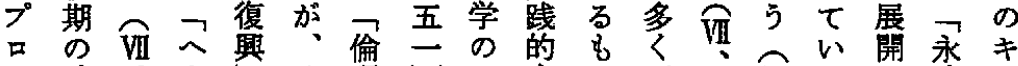
テ武、I文理

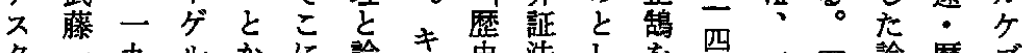
夕一九ルかに論 ル史法しを四二学論歴

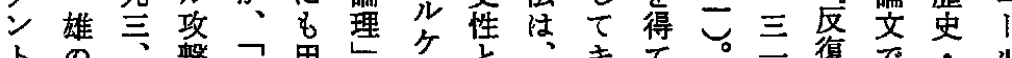
の の 論二 整 キ 田 韭交

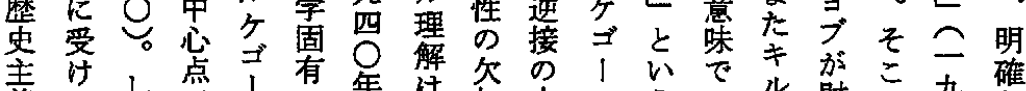
主義つし 点

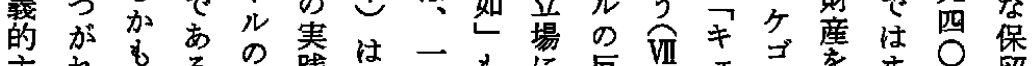
主机を る

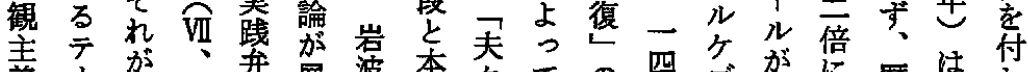

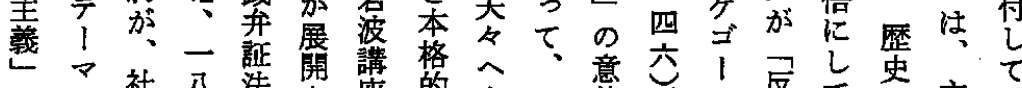

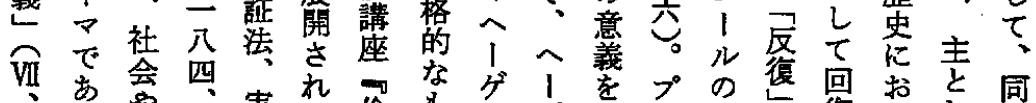

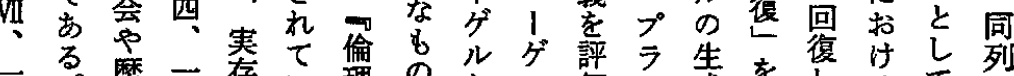

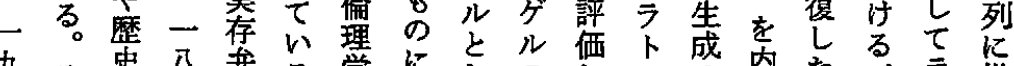

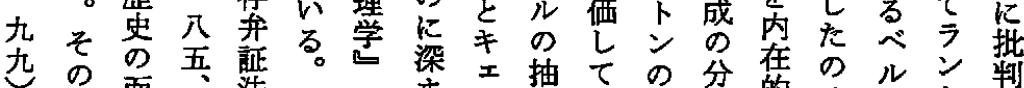

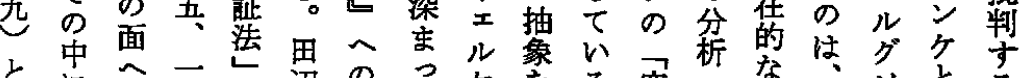

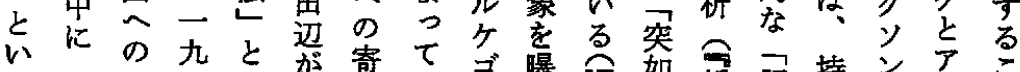
うキ 創 劣

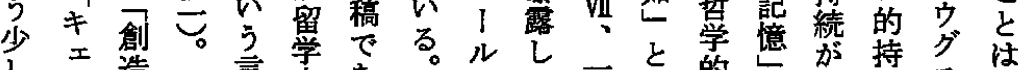

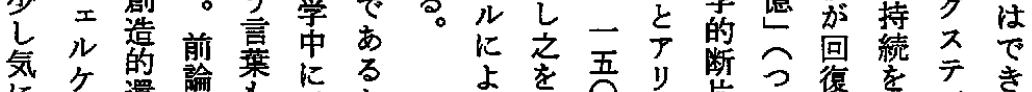

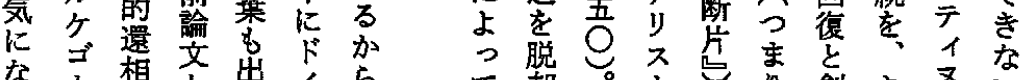
な 1 相文出出

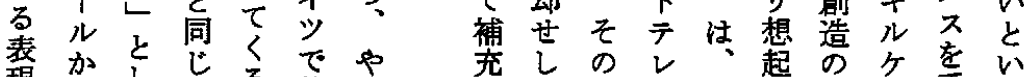

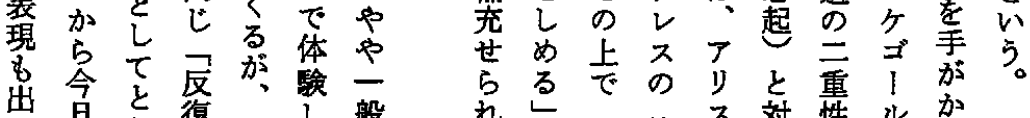

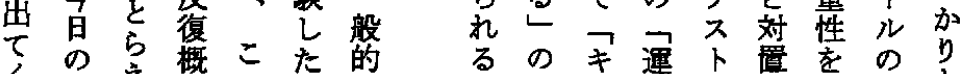
$く$ くえ概こた的るの運卜置索のり

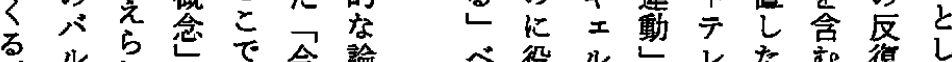

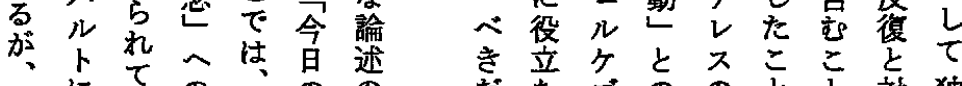
に心のの的占

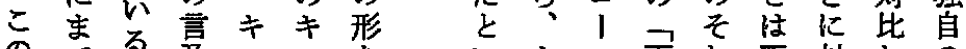
のでる。吊ルエをカ两机正対しの

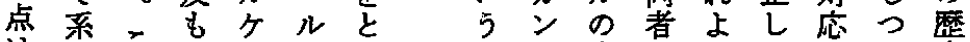

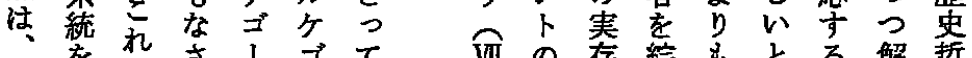

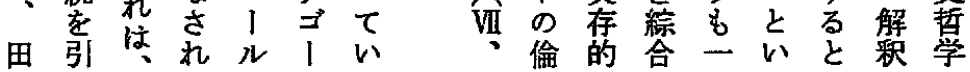


要 要

な素こ

主染の

流なよ

を構道に

成 方田

守開辺

る 少

れ学

そた。

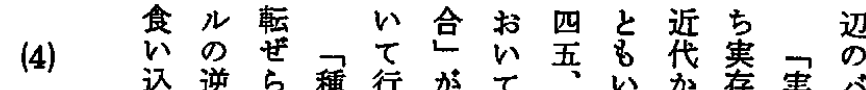

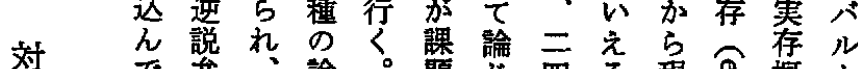
で弁、論。題迌四る現孚概卜 き証却理方九代空念理

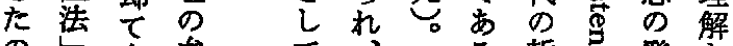
で有贲示論今 あつ場法さ文要。者范哭

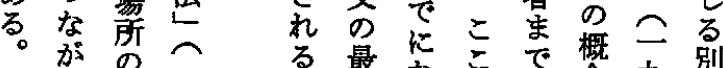
かる最なこで䈍九別

な 第 開

る 四の

著期

作 抒 期

のけに

時るお

代田

澒辺 $\tau$

宗は

検矮 キ

しの ケ

$\tau$ 固 $\exists$

み有 I

たなル

い展の

開 思

の 想

中

で

キの

儿哲

ケ学

$\exists$ の

I 根

ル 幹

$の$ 部

思 分

想索

注な

\& 本

○㑭

と 的

\& 構

論

点無 苜

て る

的否

䜣 定最

、輽

三媒論

三乔 部

せ 分

キ市で

ケる 無

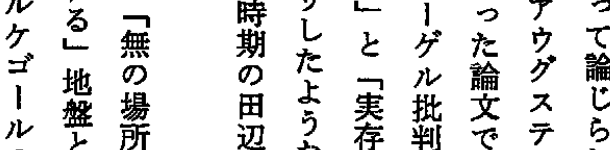

のと䋢暹な存判爻テら

実务場学形超尔る

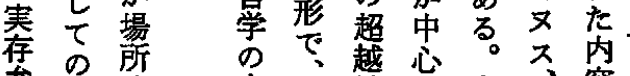

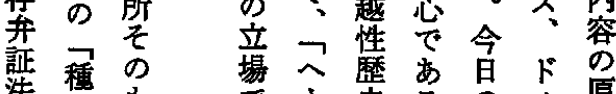

法のむで、史るのウ原

は猃の焉性る概ン型

田理無 ると代念ス提

辺性種 $\neq \neq$ 三的不示

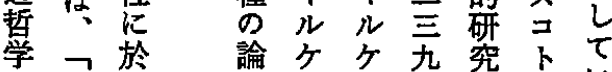

学年論㢳㢳究

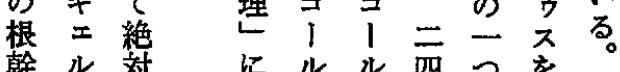

部々転結との四の就す

分 


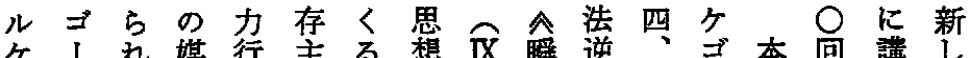
ケ、れ媒行主る。想 IX 瞬逆、羙本回講し ヨルる介信義。の、間説二1書に述い㱢 I の芹にののつ非九、弁四ルに及さ思悔 ル信の、立自を徽四し証吾のお皇想道

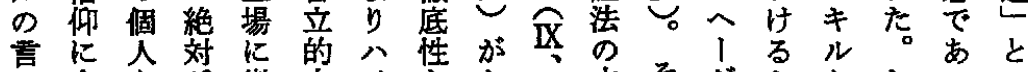

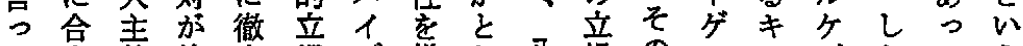

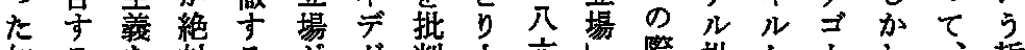

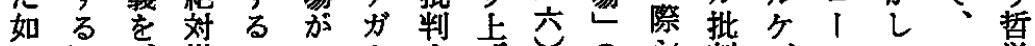
宗の 社芥 教会とにル哲のれ弁六!中ルの悔四立

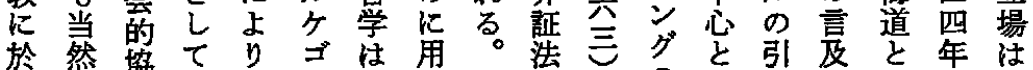

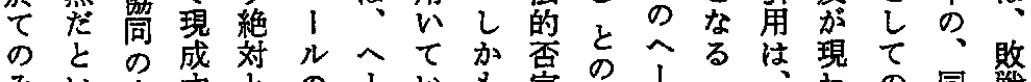
みい立卞との I

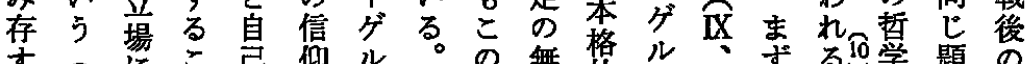

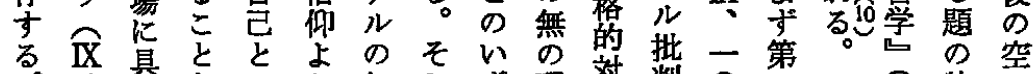

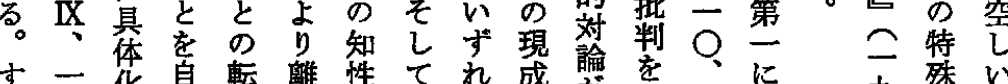

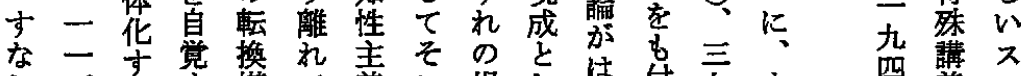

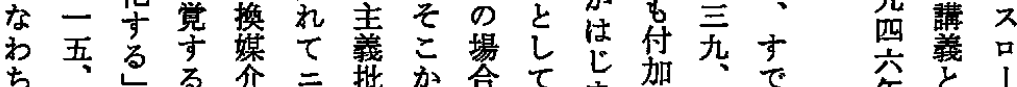

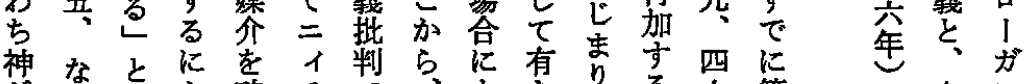

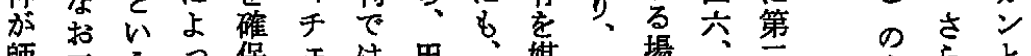

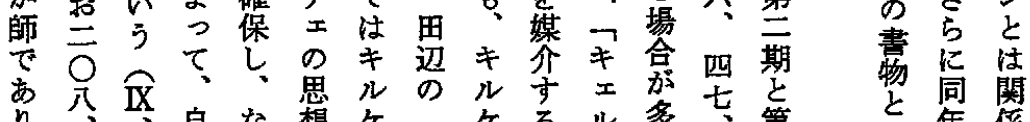

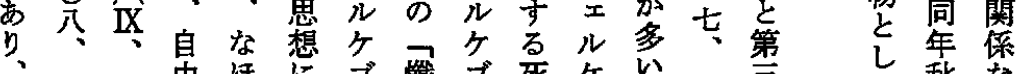

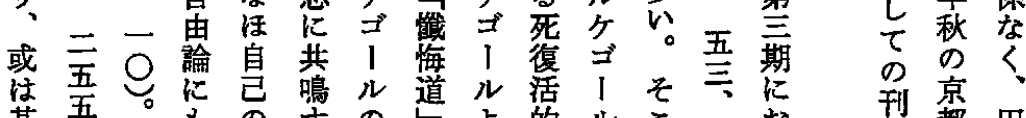

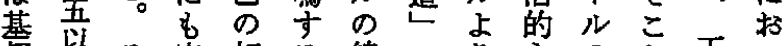
督紧を実相る線のり永の五い

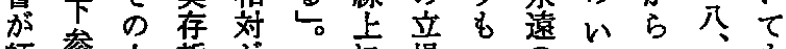

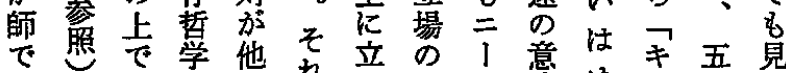

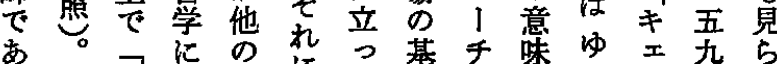

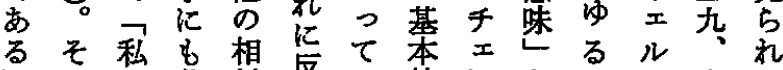
るし等対反心線にを令六た

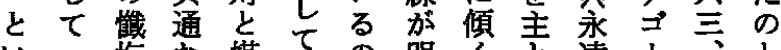
心工梅な媒樴の明く袁 I、を

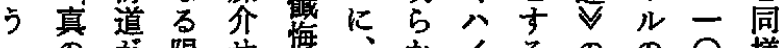

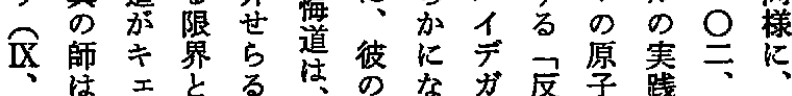

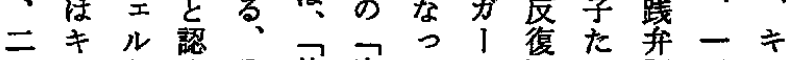

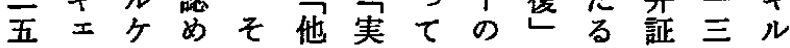




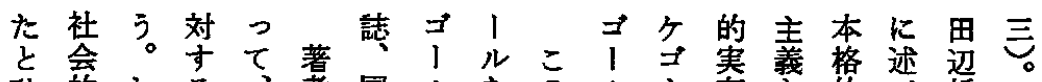

ひ的しる、署同儿をのル1存褧的哲こ

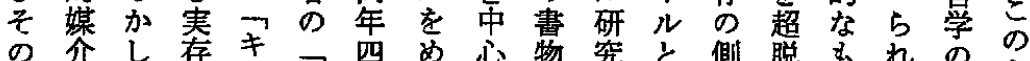

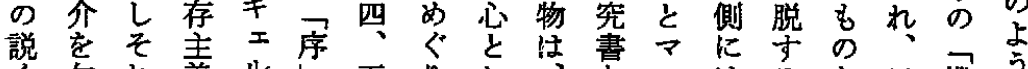

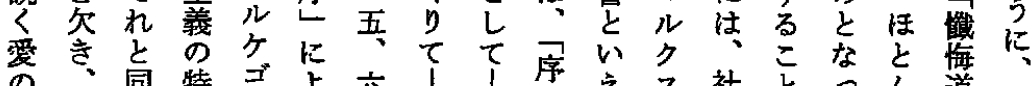
の、同特录交

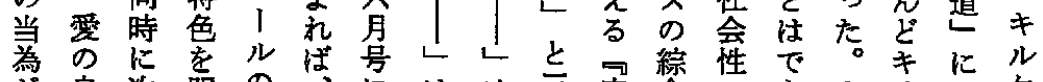

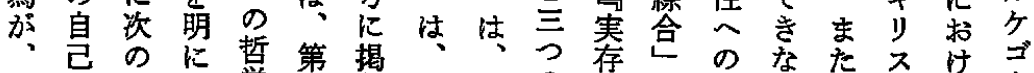

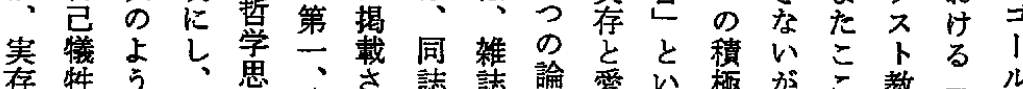

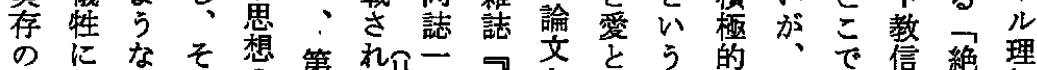

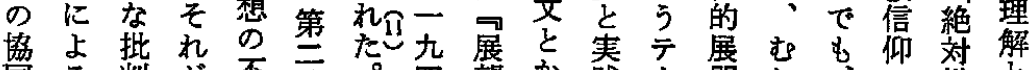
同る判加不論。四䇺か戝 1 開し、批

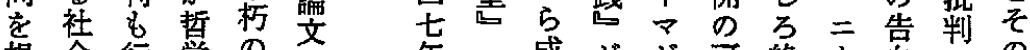

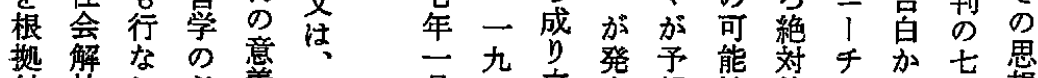
付放方必塖年四咅表想性的工花想

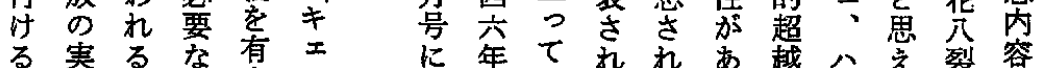

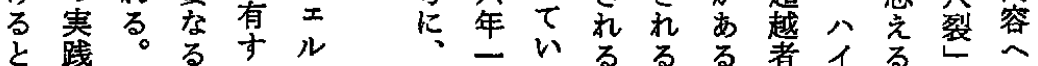

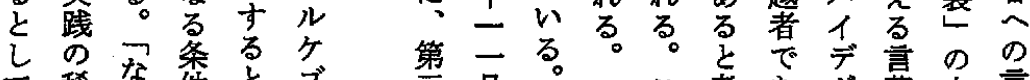

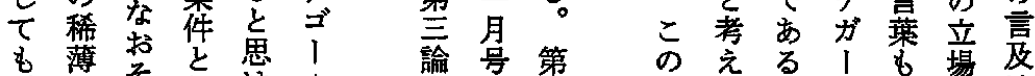

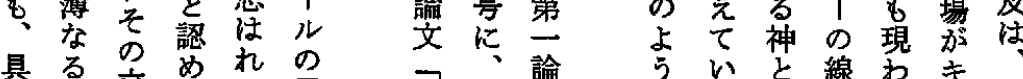

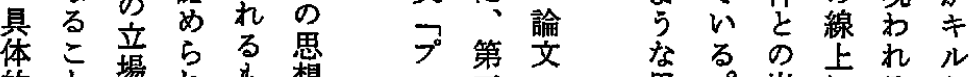

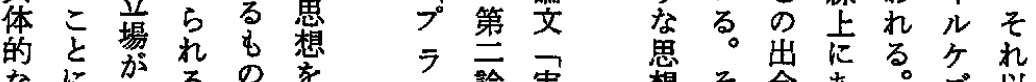

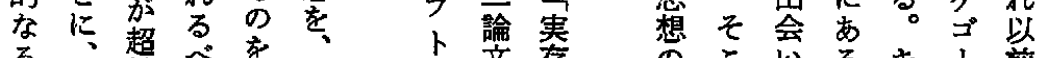

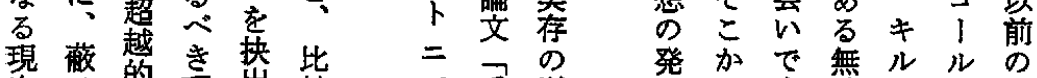

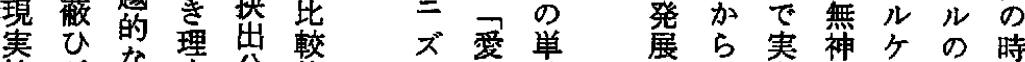

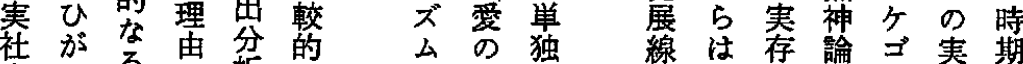

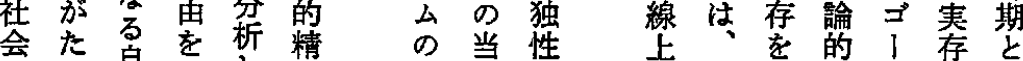

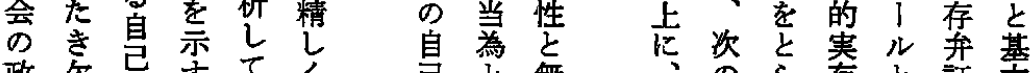

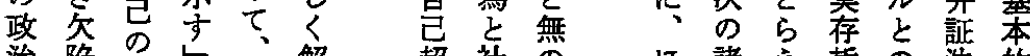

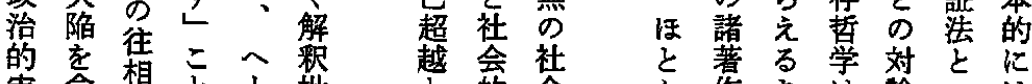

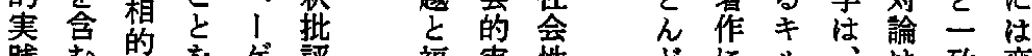

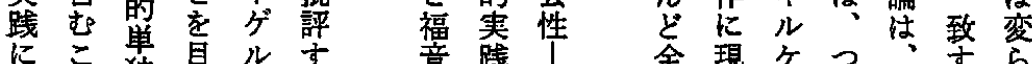

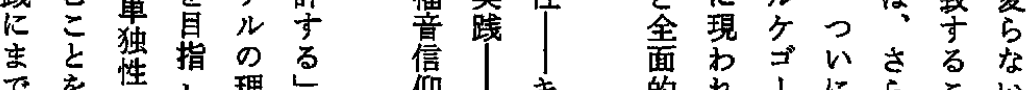

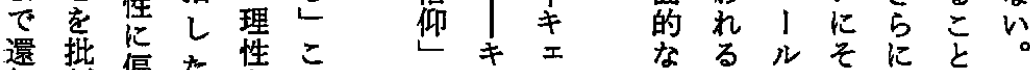

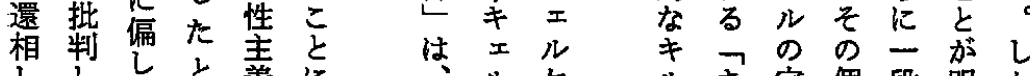

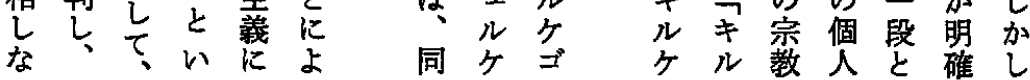
同ケゴケル教人と確し 
自筑立ち統行実展五判た想結のい 己瞦実ル立、為存艺を公はま合理た の注存の実現せの在の本、イ、妾性め 自、と主存実 5 対と手本こ論こ第見主に

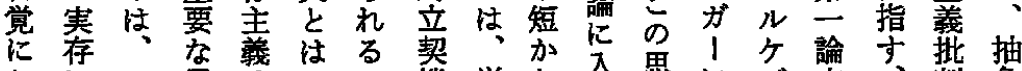
おにこ思注子の機単な思に思文、判象 いとの想、䋓がとに息は愁はでとの性

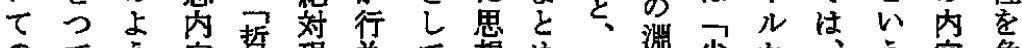

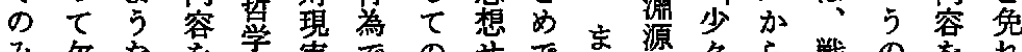
み欠な学実でのせです源々ら戦の学れ

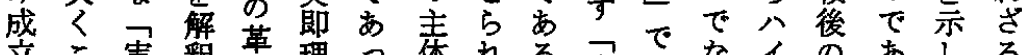

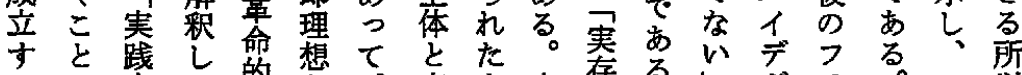

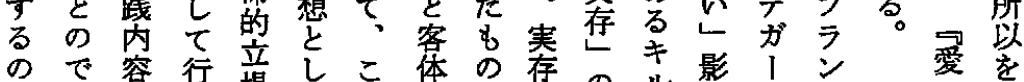

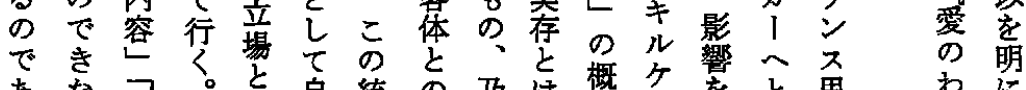

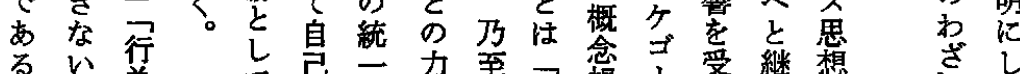

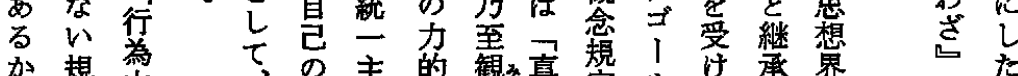

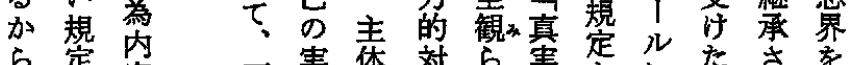

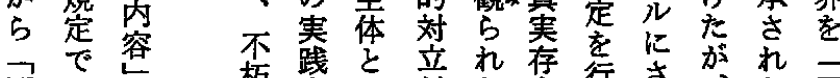
歴 あ 串る 的 社 会的う亦

環 獍 る 塂二号

定分彼 せ 作 机儿有 るかな 。寒単

ᄂ 存 独 たは者 方 厂 自単是 の总鸹 自々 賞て心

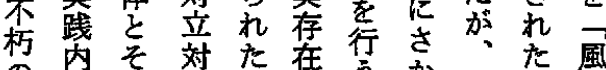

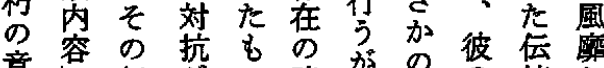

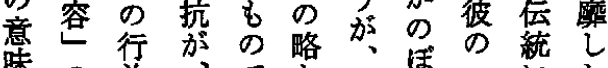

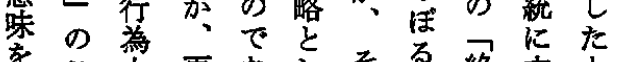

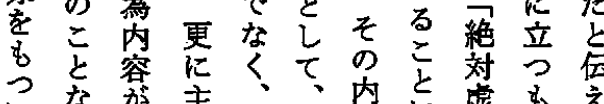

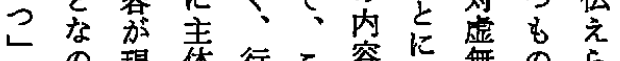
との現体行こ容に無のら

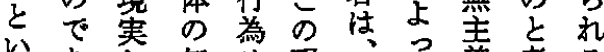

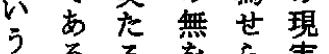

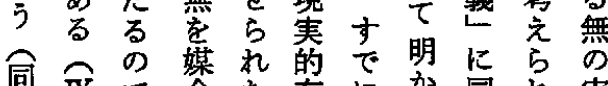

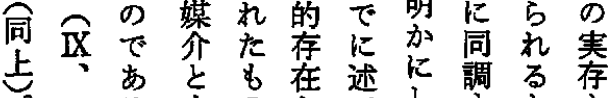

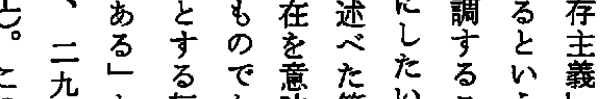

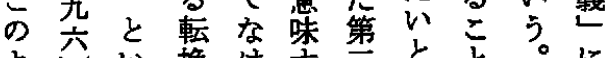

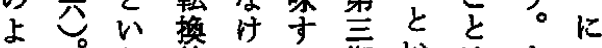
亏方的九る期法す心

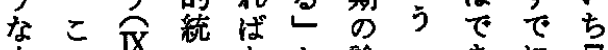

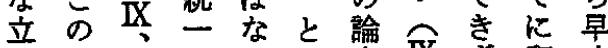

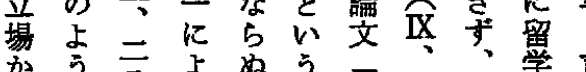

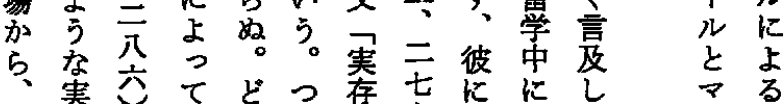

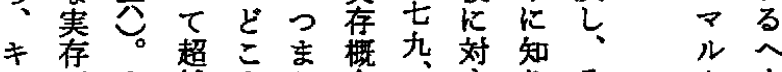

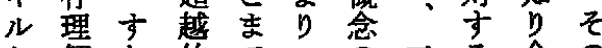
ケ解な的飞高二る合の ᄀ $\exists$ 江わ汇現発入批口思

のル 


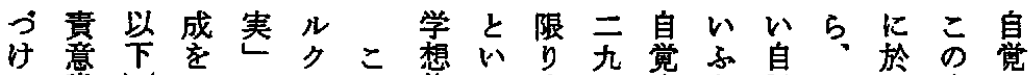

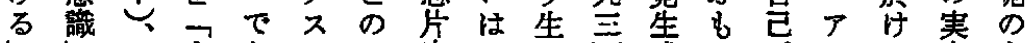

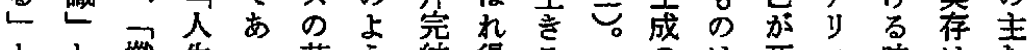

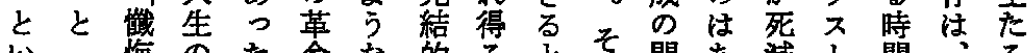

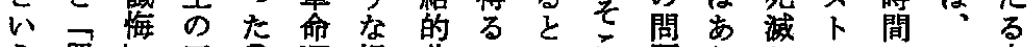

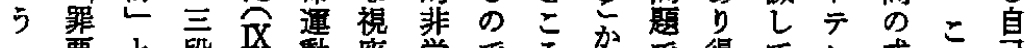
往悪と段 IX 動座学で ろ

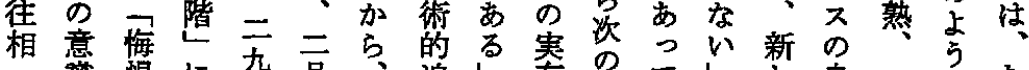
還竜 恨 に

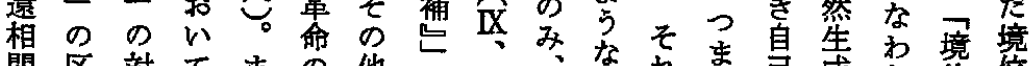

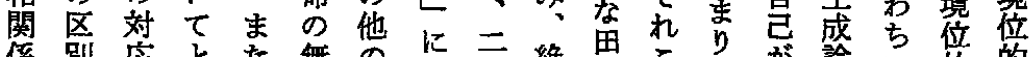

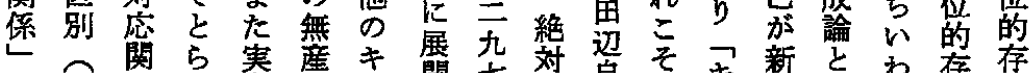

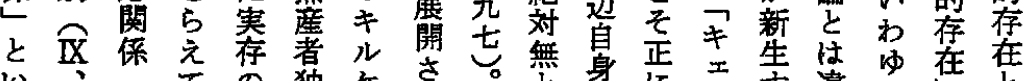

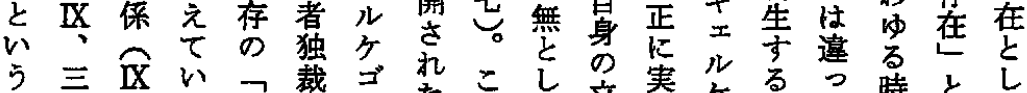

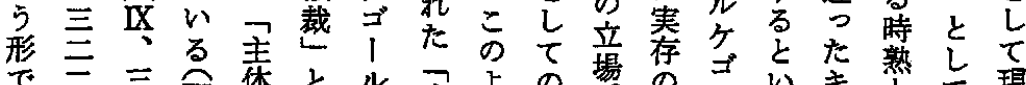

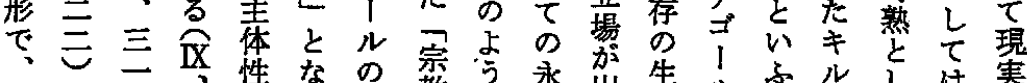

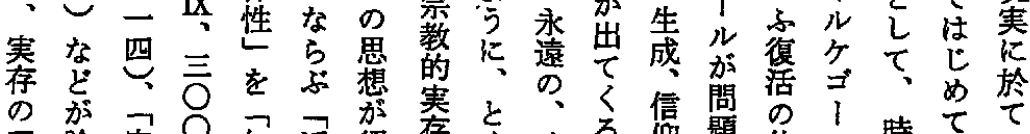

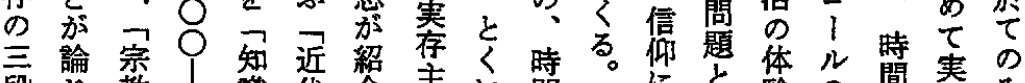

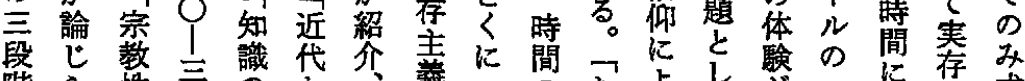
階 ら 性三の加、義 にれ A 二主 $ら$ 検 おる。

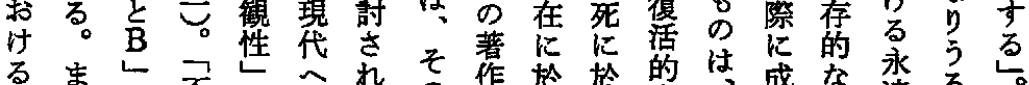

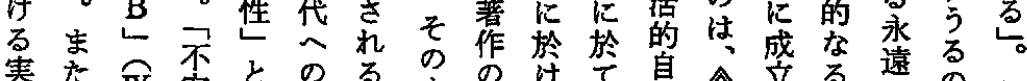

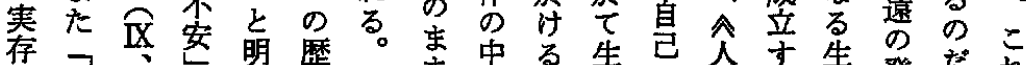

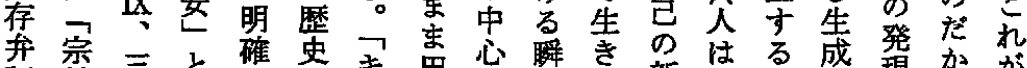

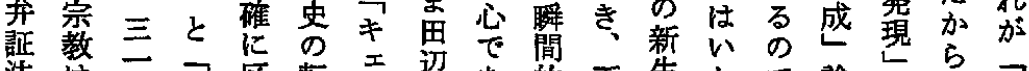

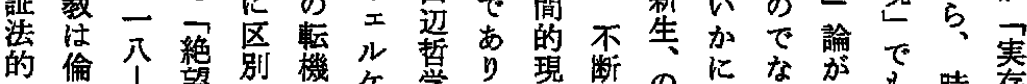

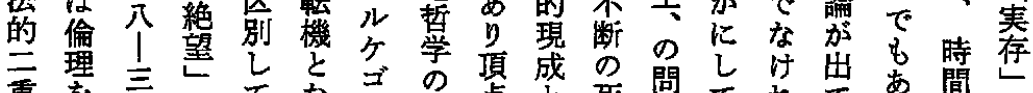

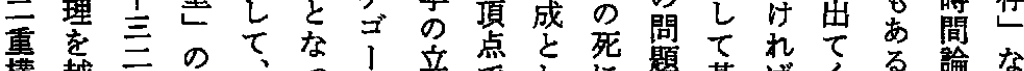

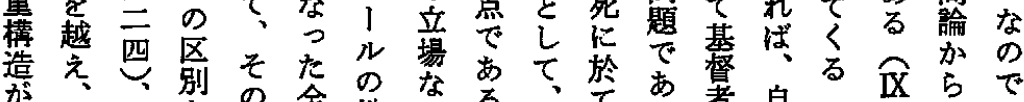

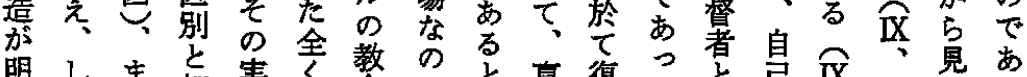

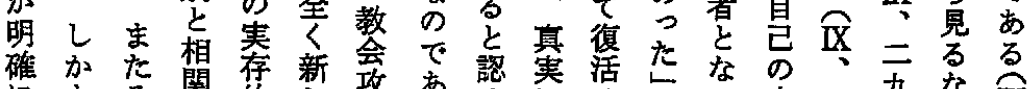

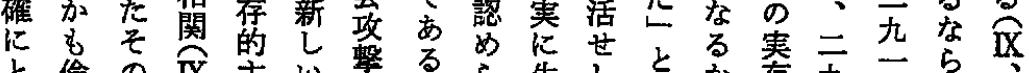
と倫の $\mathrm{I}$ 圭心慙る。ら生し

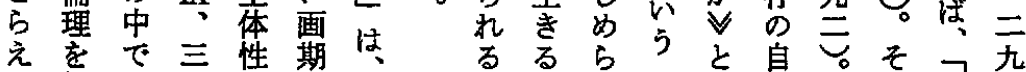

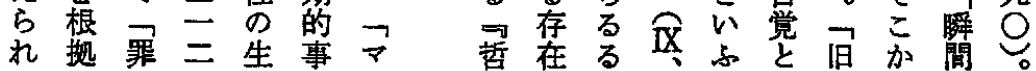




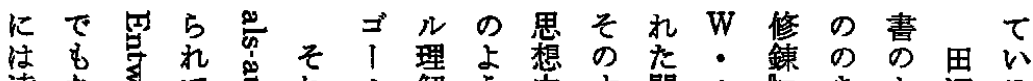

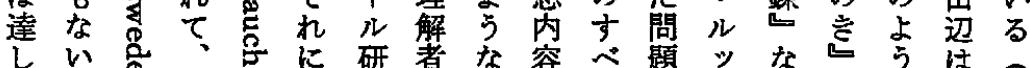

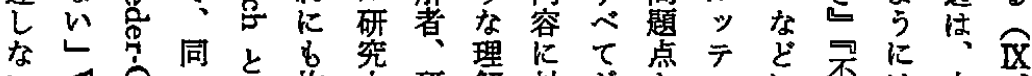

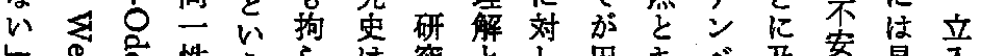

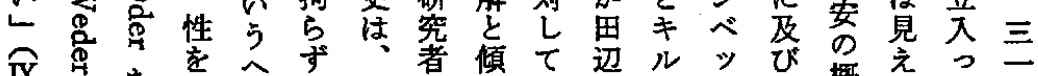
X

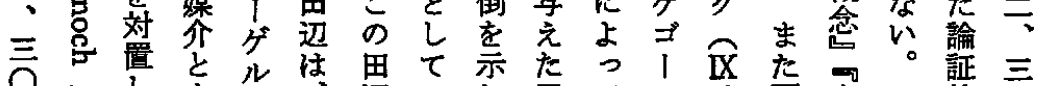

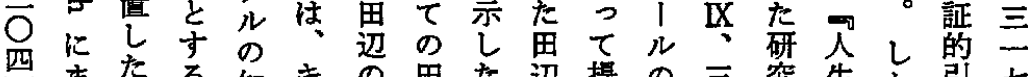

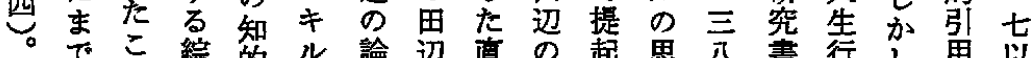
$\neg$ 徹と綜的儿論辺面の起思分畫行し用以

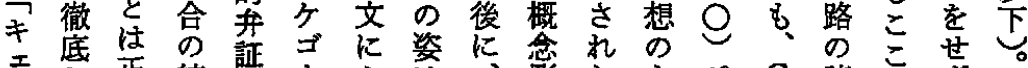

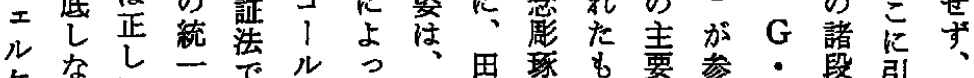

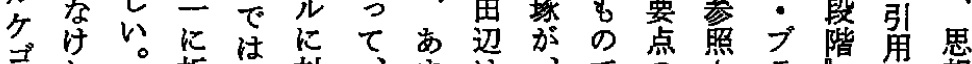

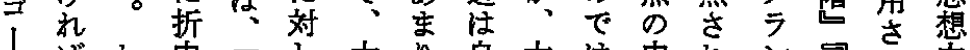

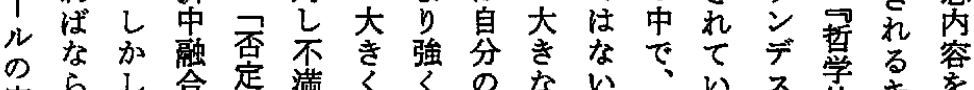

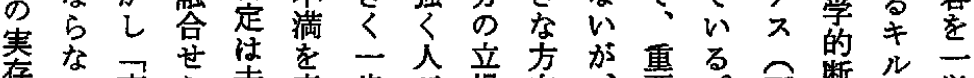

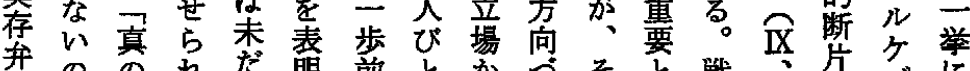

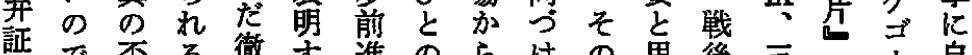

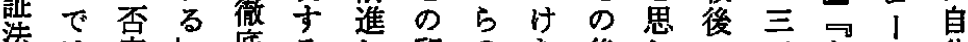
法は定。底る。印の後わの三あル分

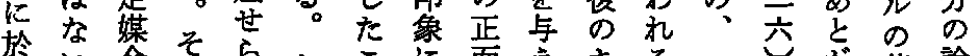
於小芥そ方たこ面えキる一六怔著論

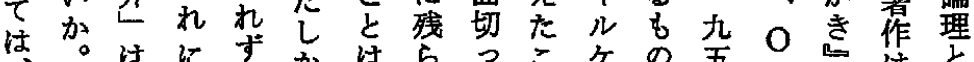

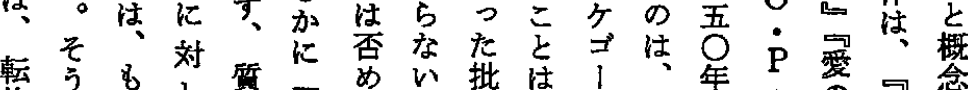

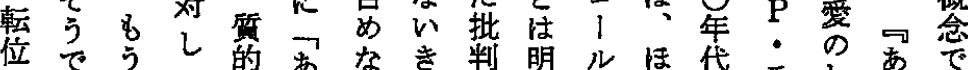
なて的あなき判明ルほ代モわ市で

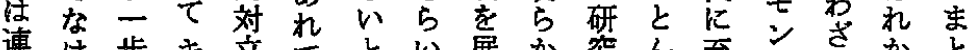

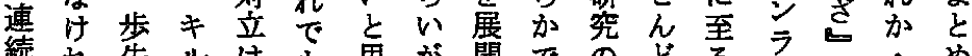

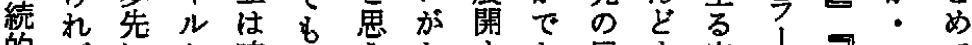
的ばにケ暗あう市尔あ展す寒占死こて 発進

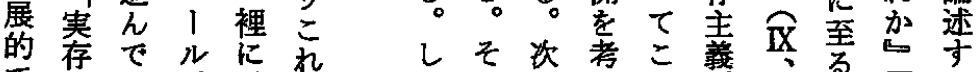

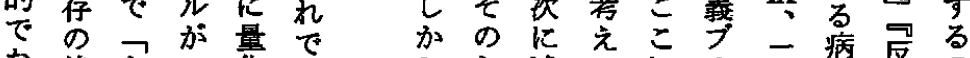

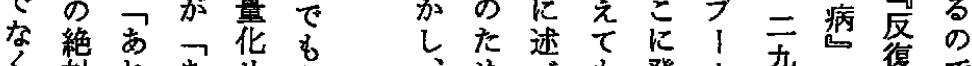

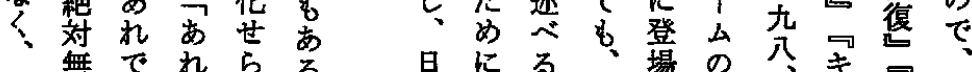

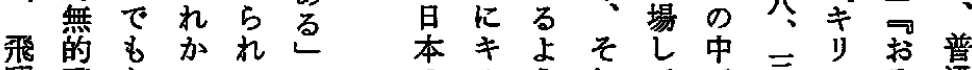
躍飛なこーのルうう通 的躍くれ様导尔にぞ、論吾下れ市

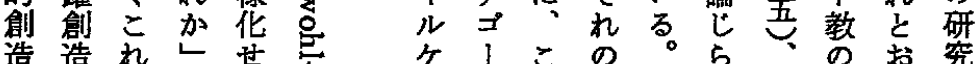




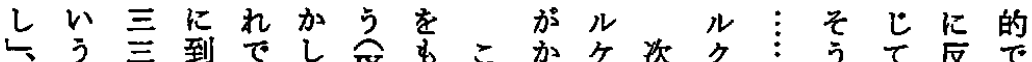

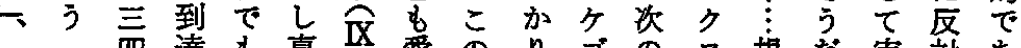

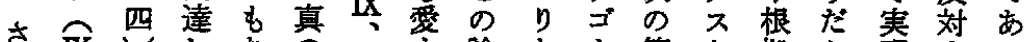

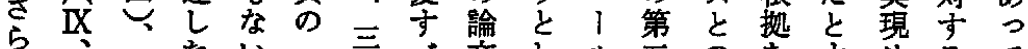

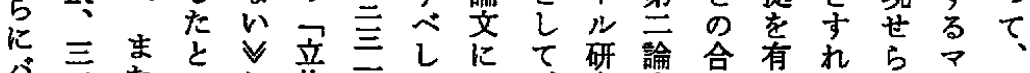

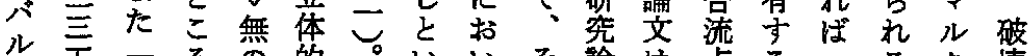
吾弁乃异的。いいそ諭は点るこるる壊

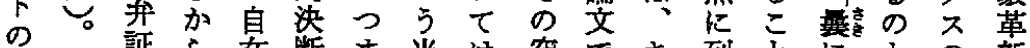

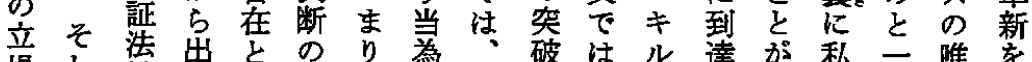

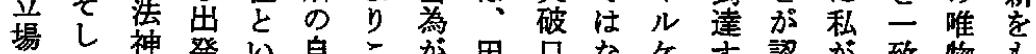

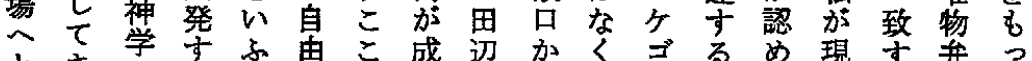

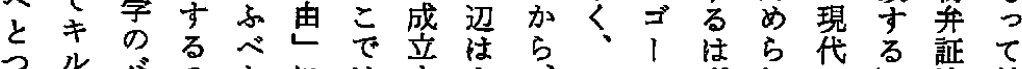

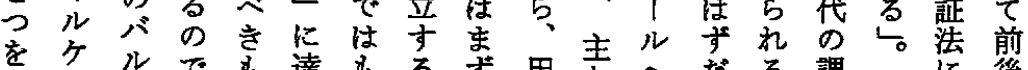

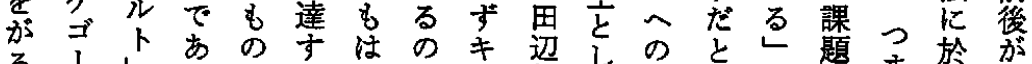
る

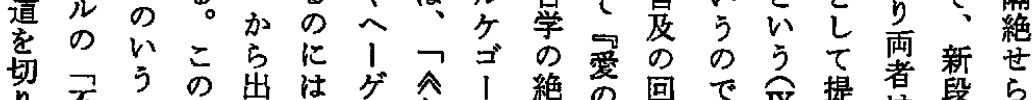

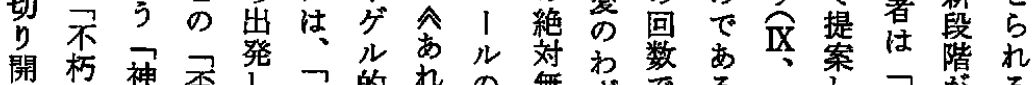

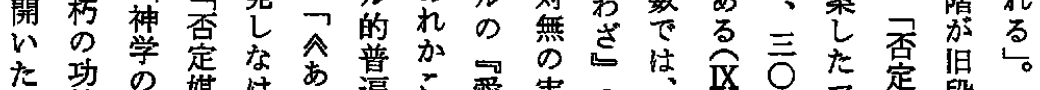

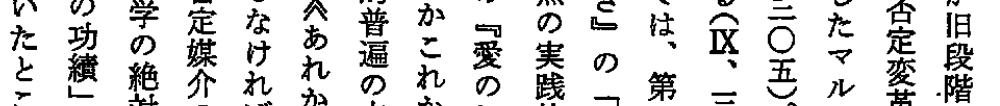
こ䌙 絶 介 れ れ ろ 注否立な れ 場

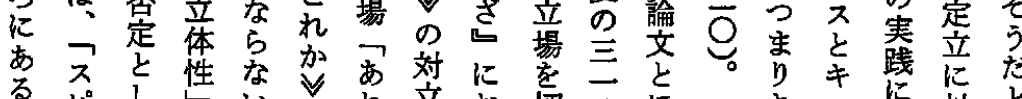
る

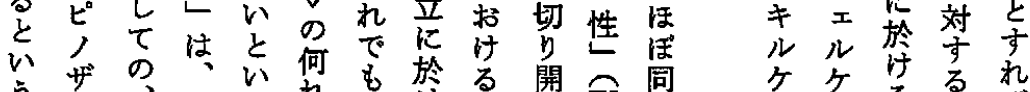

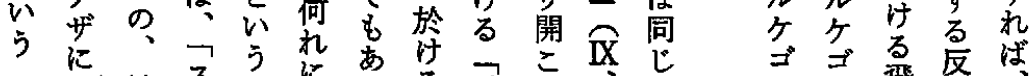
IX 兆神

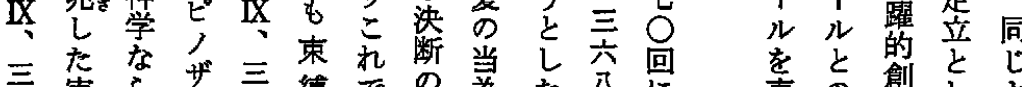
三奉ら

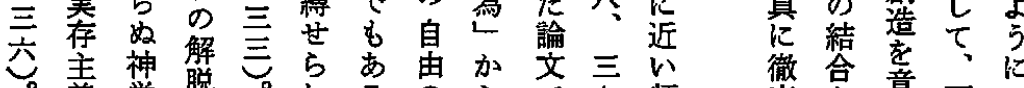
義学脱

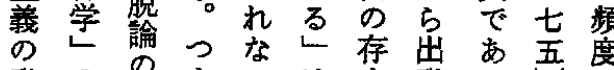

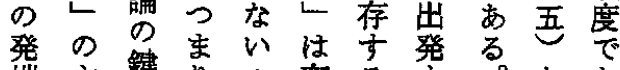

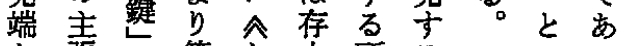
を誩で第 あ 立 所る。

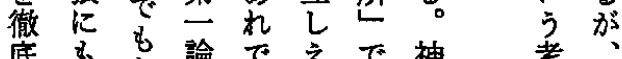
底通あ論で 文ず神考 にしらのなる 展る IX 最く。を隣文や 開と 後こしい人手 キ 


\section{講演}

辺ᄀルら能てをルのすちにキ約ル咅

はキがぬに寒根さがべに属儿的は場た

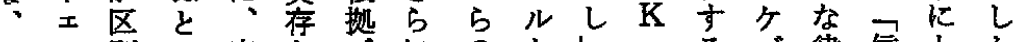
こル別い実をうにのケレ・るコ律信とか のケしう践自け田離ゴとバ云 1 法仰どに 論コた無的賞る辺反了いル重ル主そまキ 文、宗の当古有の索ルうト存と義のりル

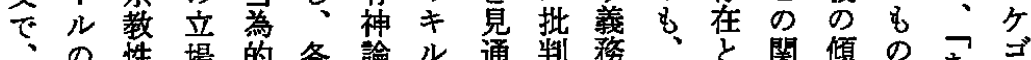

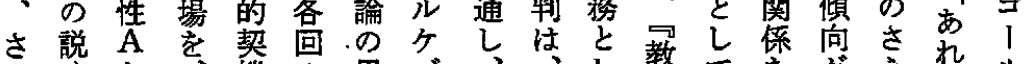
まく

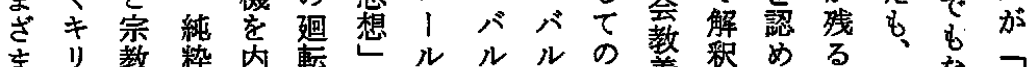

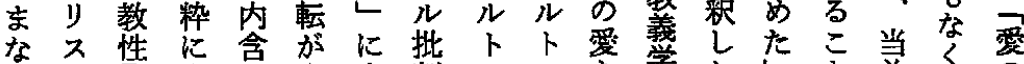

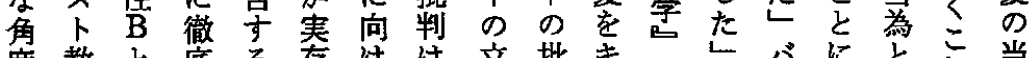

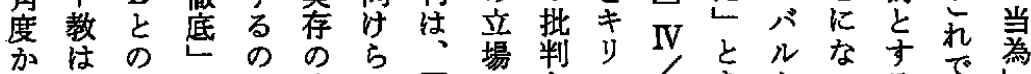

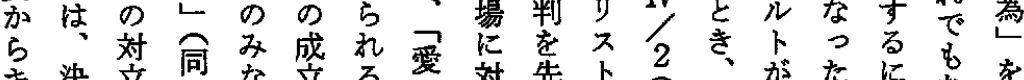

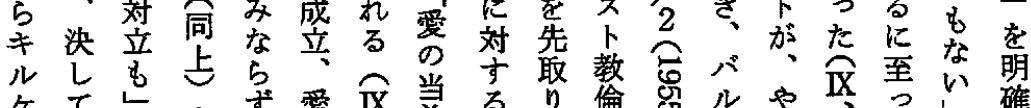

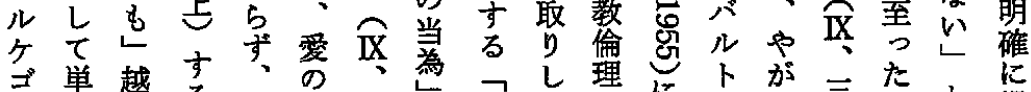

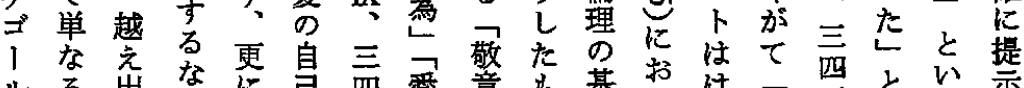
ルる出なに㞯四票意塂は罗とい示

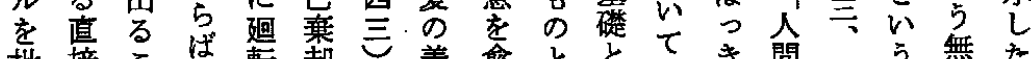

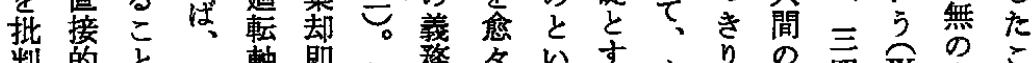
判的々 有軸 即む務名

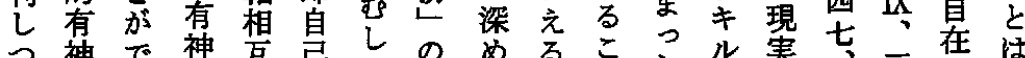

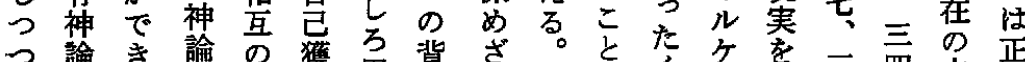

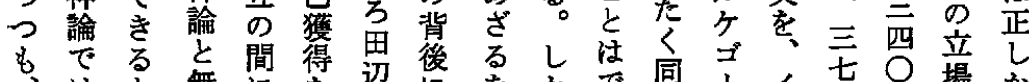
いな ๖い:

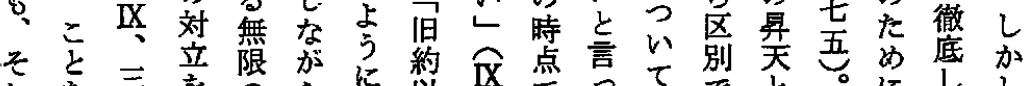

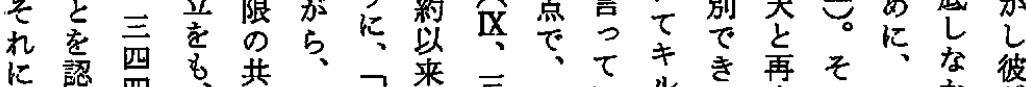

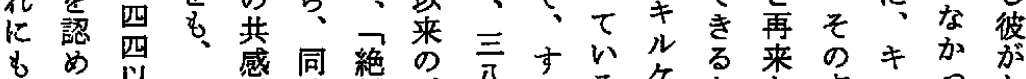

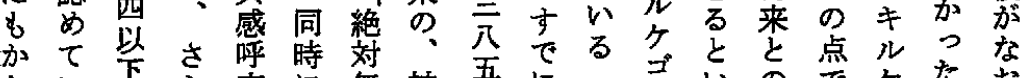

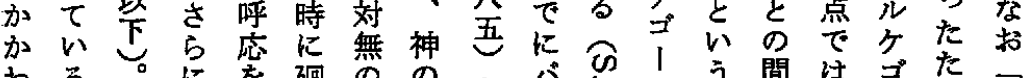

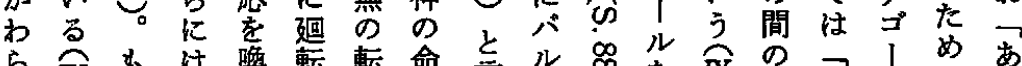

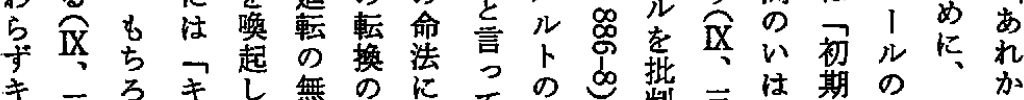
キ三ろキし 無のにての

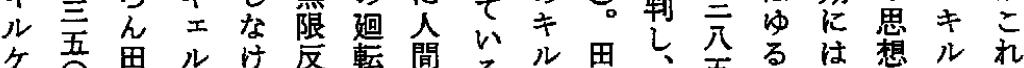

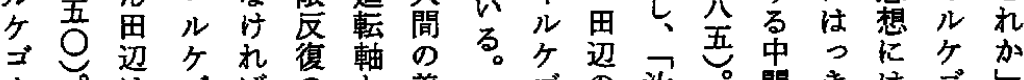

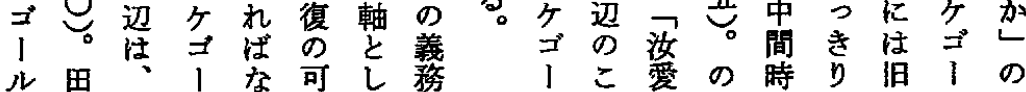




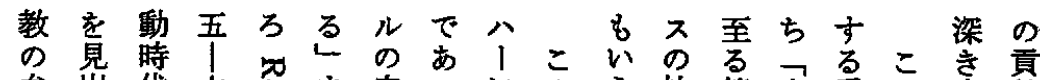

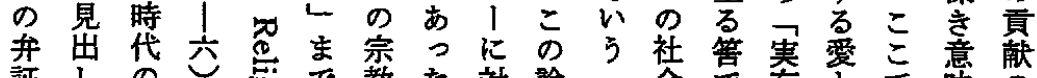

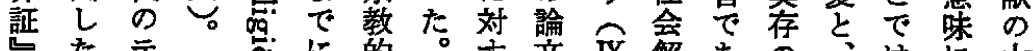

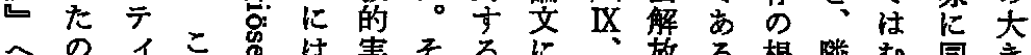

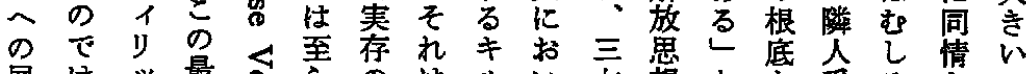

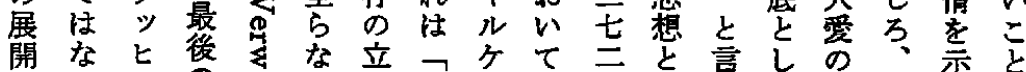

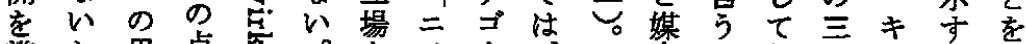

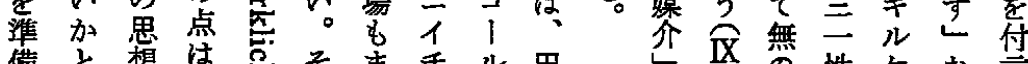

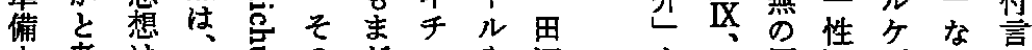

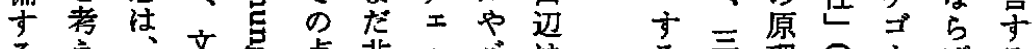

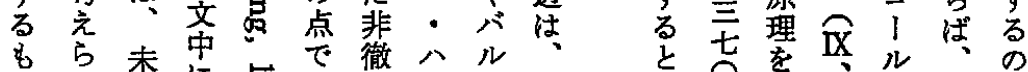
も方桀整で徹八ル

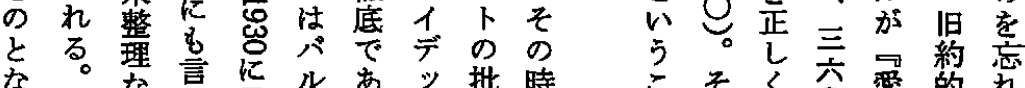

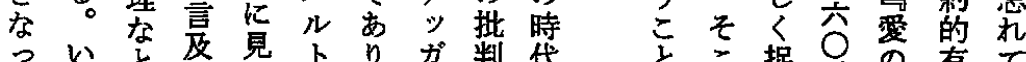

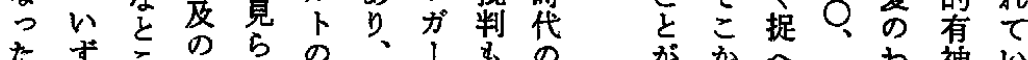

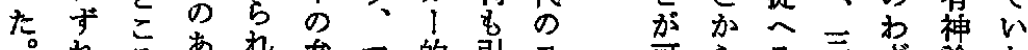

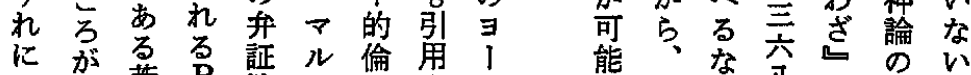

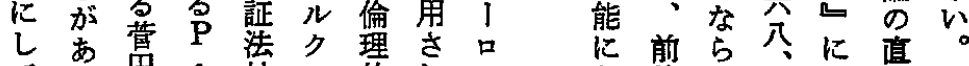

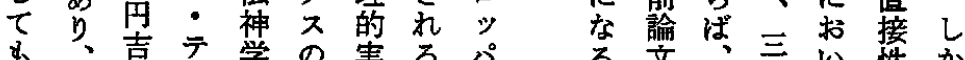

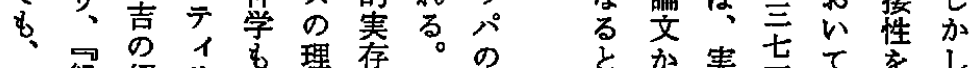

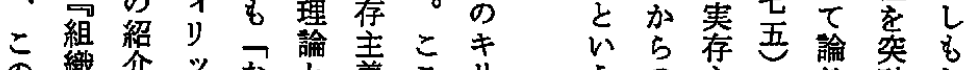
の織丒ツなと義こり よ神にヒ結些で う学よの十びのむた な㓯分口限出教 キのと想纪く界發神

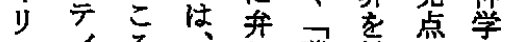

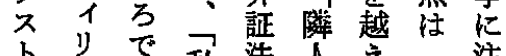

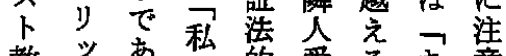
教点离台的雲るキ意

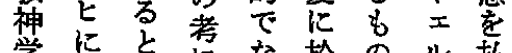
学纪考虎な於の儿払

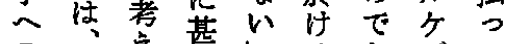

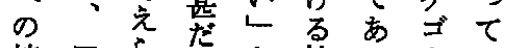

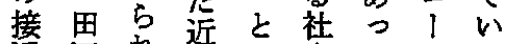

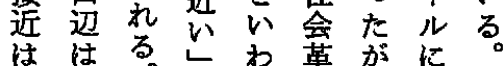

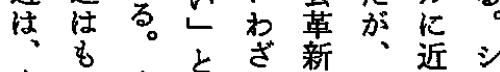
次口宗点等こ芦 のと教占春の宗引

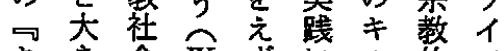

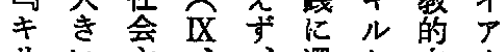
少至、還方立 I

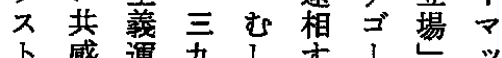

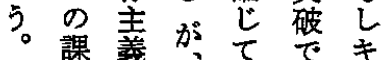

そ題注いきル れでそ絶るたケ は岕の対るで る単無露あ I 親 ᄀ独ののるル 第キ性三三うが

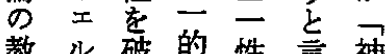
教尔破贸性言神 導 $コ ゙ て 介$ 主 加神化? 同義 れル子転ま上 たの同せり气始 所基胞 5 氺

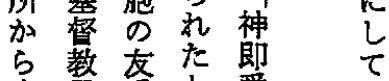

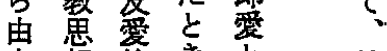
来想䪨き文終 すを社な るマ会す神る しル性なに無 とクに放向 


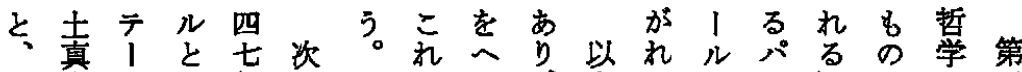

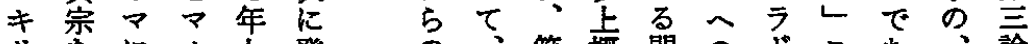
リをにル九発の、第概問のドこあ、論 ス媒展ク月表著キ至観題言ッをる要文

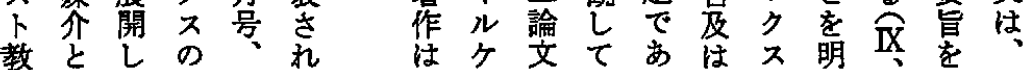
符て結のた おるき合ち 論 けキた育文 当少名名注

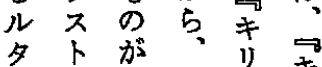

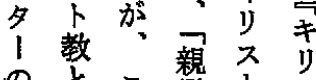
第禅 次 宗媒で導証字 孝花は品心

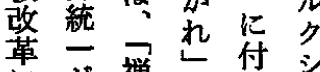

に架椫て録

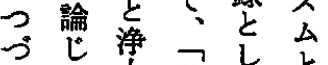

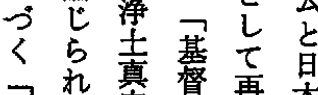
第る机宗督再本 次仏想想で教 宗孝紊点あ

教に界々る。第

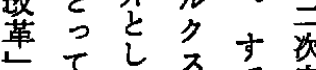

な注て元で宗

の鎌の社に見謷

で倉念会見䩦

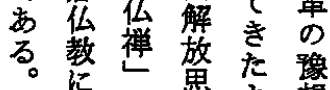

お加想よ想

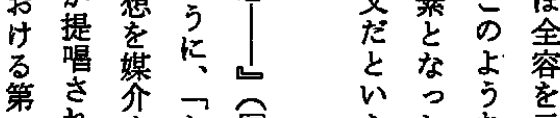

杂夺キ展省たな示

祘さ主望

教らと皇

る の 理 し

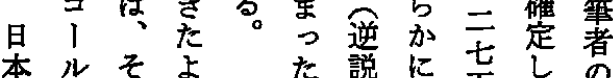

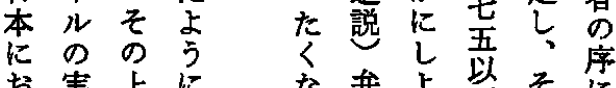

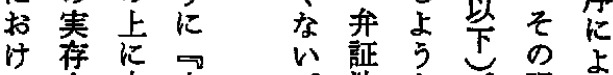

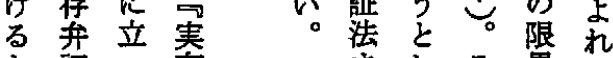

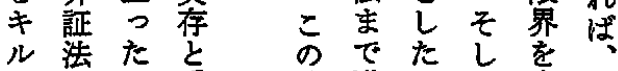
ケ毛第進とて究 $\exists$ 思ルを 等めいフ明私 1 想々寒論らう科し肪 儿注录践妾机学、哲

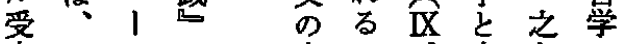
容田ルの内こ、宗をの 史辺と第容 の暂の注をと解と 第学本論、要六の補し 四の格文む求哲完て 期一的注标学守今 に方な、るるプにるま 現の対田次卡於市で わ柱論辺のと付の最 れをののいンると它 たなド キうの媒し有

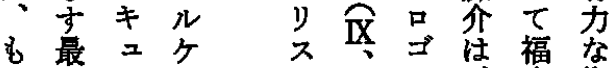
○メ と重ン I 教士贲愛信導 要卜ル次証の仰を

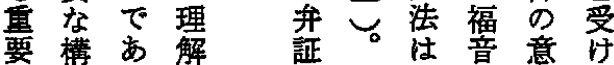

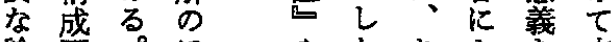
論要。ほか未よを来 文素こぽ、しエっ確っ た方全哲そルて集た となよ容学のケ始しと

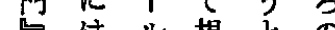
でで解たキの扰試プ であと論引ルい付みラ

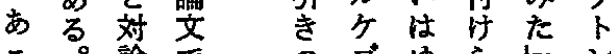
蟞に浄 


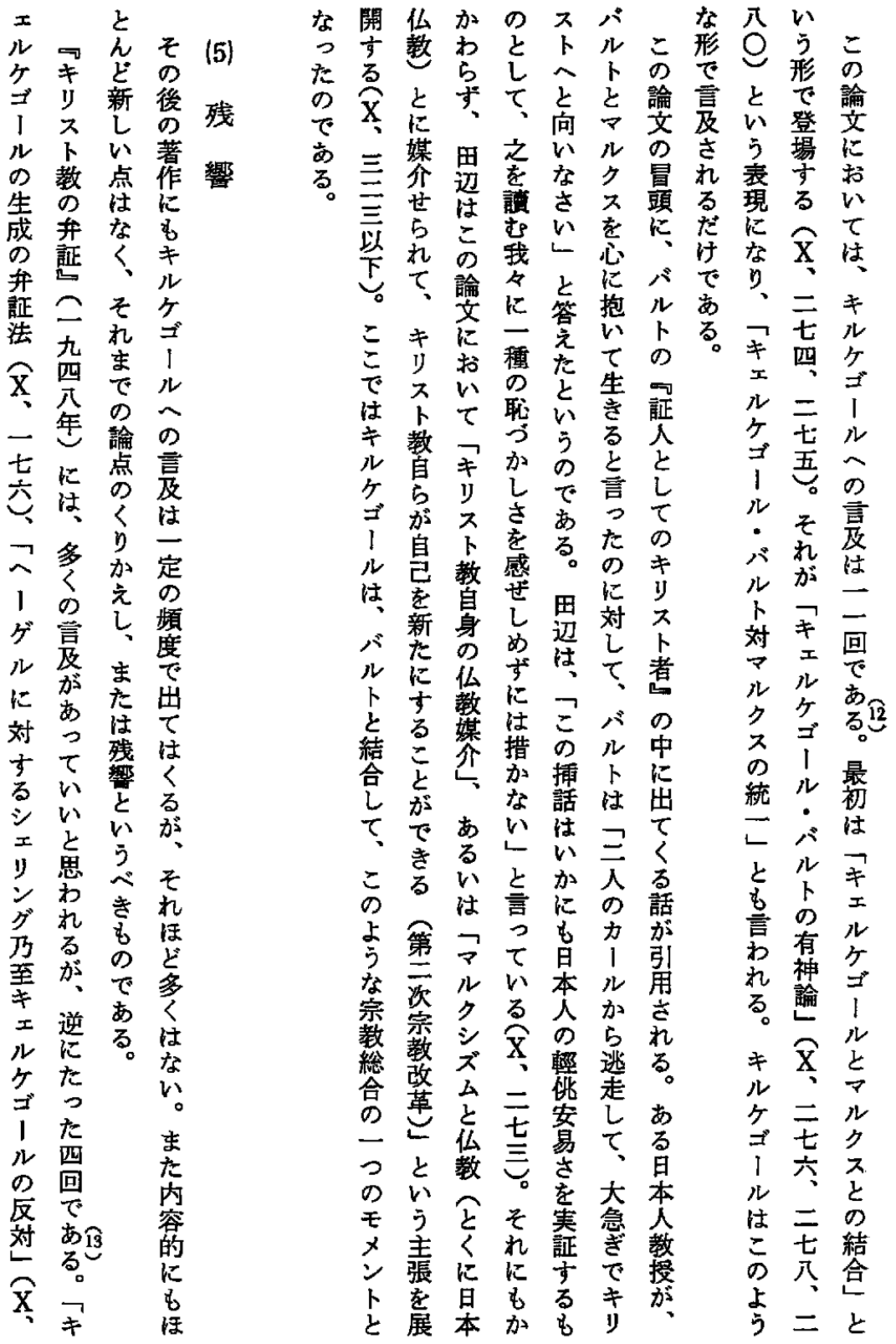




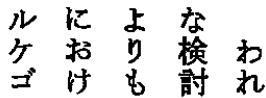

】るはをわ

ルキる加れ

の迸尔充は

接

䒪 1 沉た論

証ルで。文

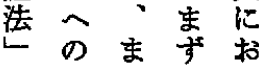

とつたこい

二接梁の?

致 近さ概

寸学観田

るのを边

飞時 ち 5 哲

言 期、言 学

$口 k$ 本えの

て掠格る全

Wい的こ著

るてなと作

第そま它琴

四ので田わ

期時あ辺机

の期るのた

$\neq$ 元 $\neq$

ル田いルル

ケ辺らケケ

$\exists$ の こ $\exists コ$

I 立 | I

ル場でルル

とであへへ

のあるのの

る。加言

対寻方吊

論種でわの

ᄂのにりす

の論田はこ

時理 辺、て

期の哲わを

に弁学れ取

入証のわり

る法開杂占

は予て

関 第想 概

係 キ三篗

は土期た的
ルど、遺年節の゙こっ 要 の 九

のキ稿て亥羿九哲素む

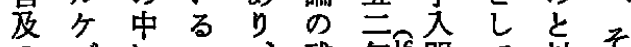

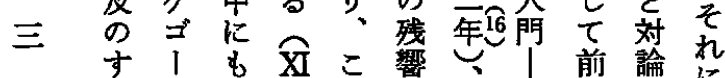

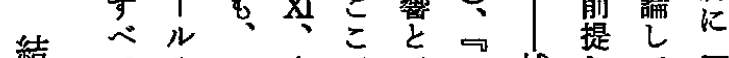

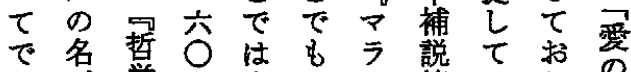

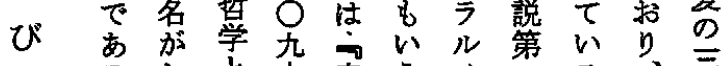

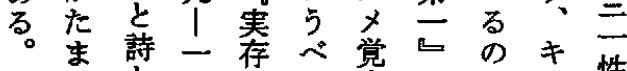
にと六とき畫へだ性

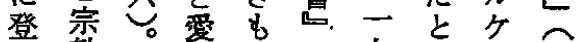
場教方の气九考 す萶で九四え!

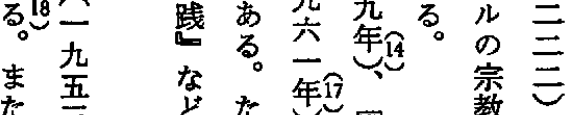

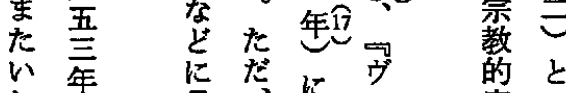
わ年学だに党 的と $\Phi$ 第守

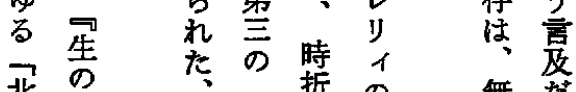
北存俥哲哲 講在論学 れ茶視け 義諞 ま大年誓 たあ に死 で門 乔学 可る も弁田にルっ 否こ

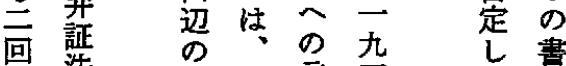
登法

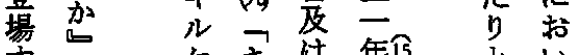

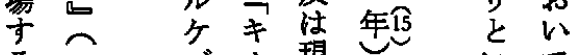
るこ ヨル現年

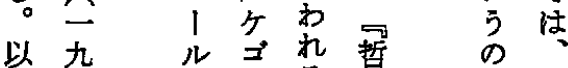
上六理 皇学で田 加三解ル汃入注辺 田年㤎の、門な注 辺 手宗す

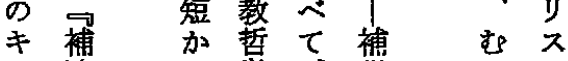
ル遗に学、説し下 ケ 4 ま そ第 万教 $\exists$ とと扎至自神 Iなおいま少学 


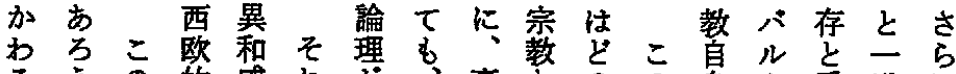

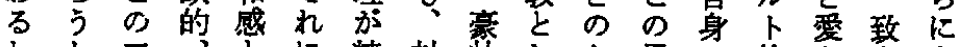

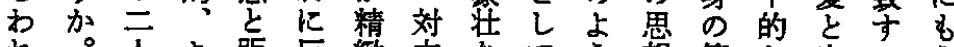

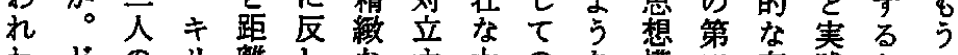

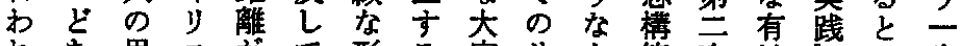

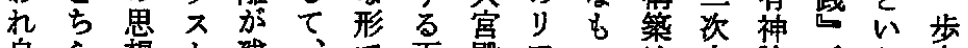

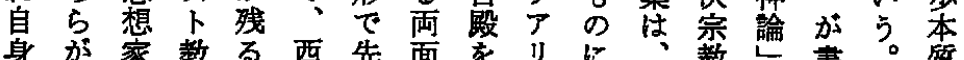

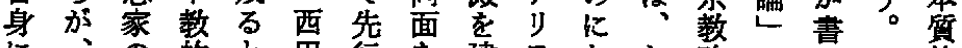

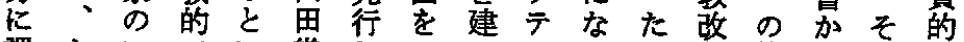
課よいでい幾し去て

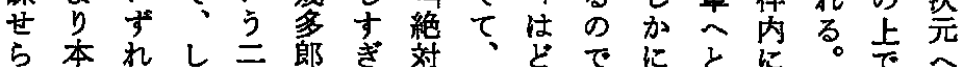

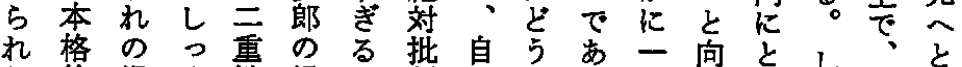

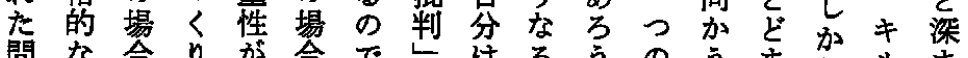
問な拿りが合でしはるうのうま热ルま

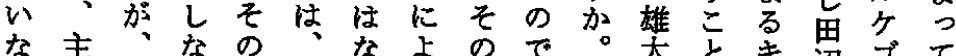

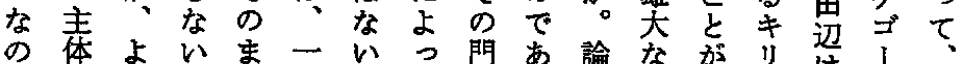

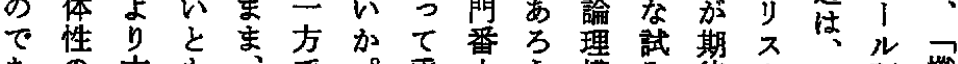

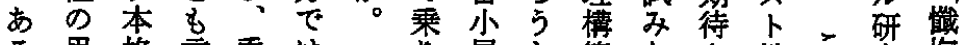

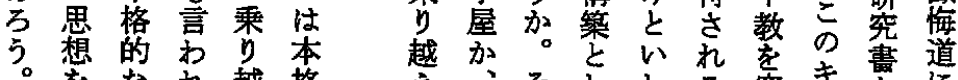

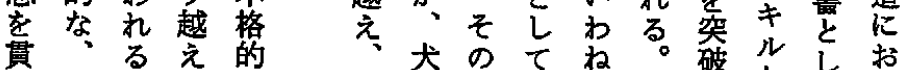

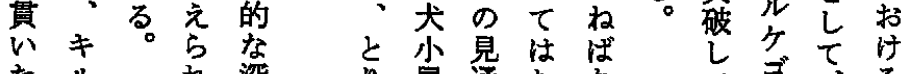
たル深り屋通たなな゙、゙る

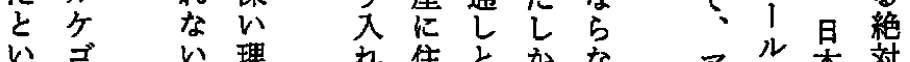

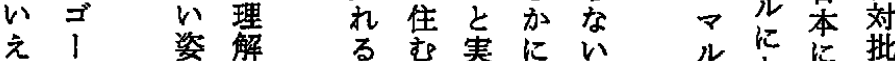

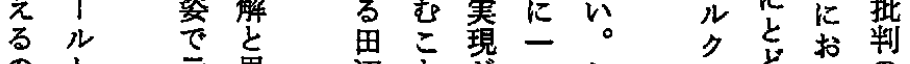

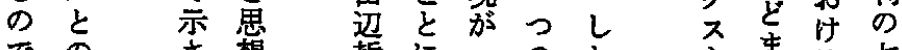
でのさ想蕣になのが主まるた

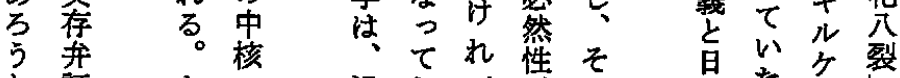
品証 キ人 沉しば留こ 法的の論ま示に そ的午接理うキさ現 れ対 $\exists$ 近主のルれ出 は話了方義でケた守

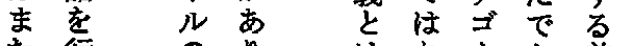
た行のり㤝な晋

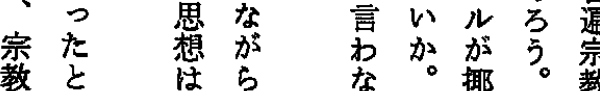

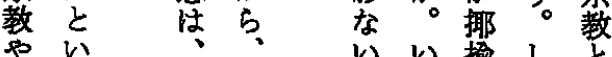

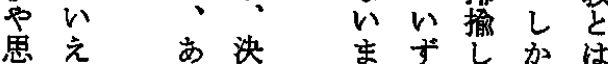
想る あ定でれたし実 にの り 的 かでにな

星た方裂

佁で、は 教住儿 には受キ 媒な容ル 芥员史々 せフの ゴ 万 $\neq-1$ 机期ル てルをの ケ面 寒 キ ゴす存 リ 1 弁 スルコ証 卜!実法 


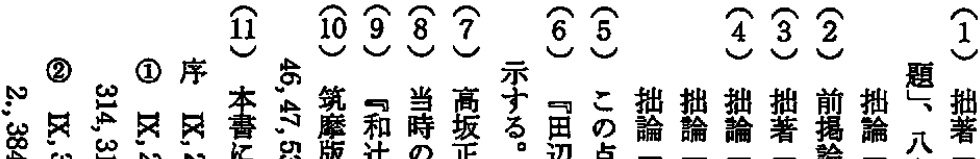

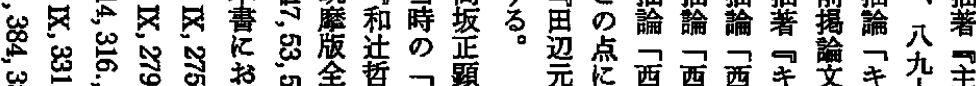
岕! 心

岕

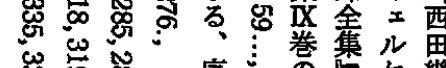

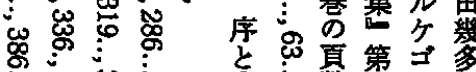

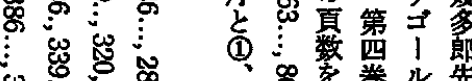
ఝ్ర : w w 崖 岕 㐘

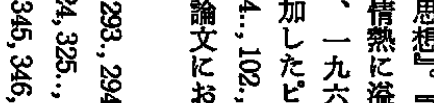

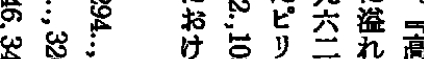

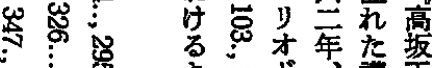

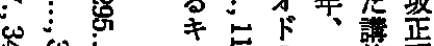

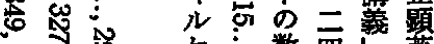

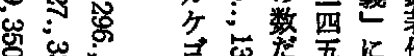

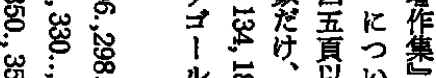
巡:

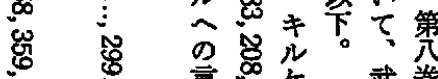

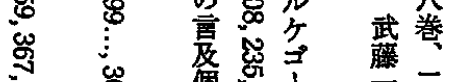

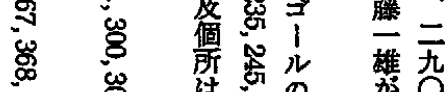

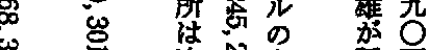
N 次岛名 語頁 荡 心 जै w

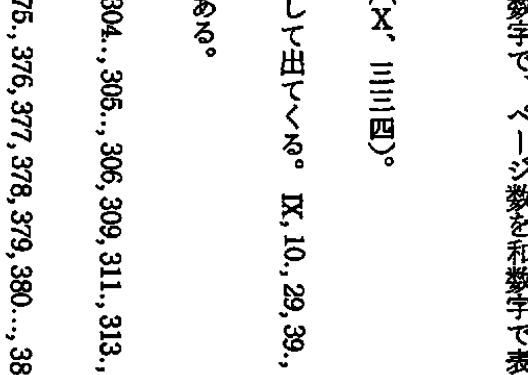
集い幾幾幾ケキケ二と 筑は多郎郎郎了光光西整 意前

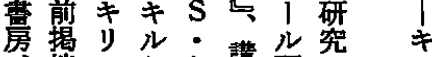

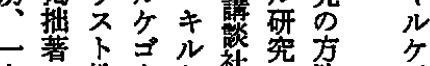
九教「社の法妇

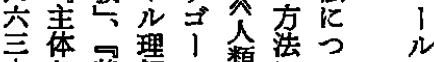
言基解儿類に心法い 加

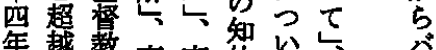

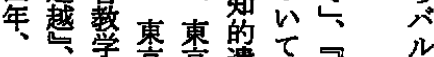
全二研娈京遗基

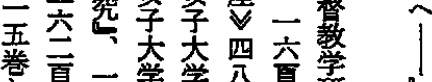

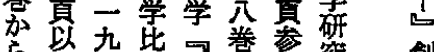

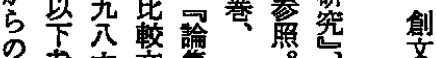
留吝年花隹九京社

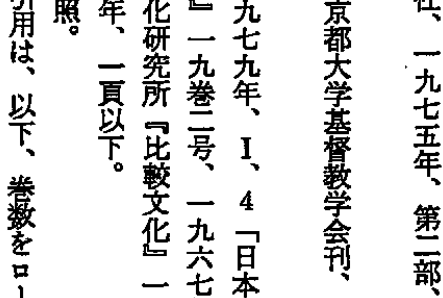

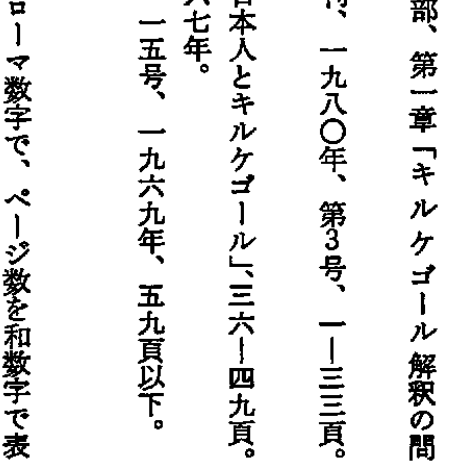


(2) $\mathrm{XX}, 471$

(고 $\mathrm{X}, 274 ., 275 . ., 276,278,280,290,291,299$

(모 $\mathrm{X}, 8,179,190,222$

(્ㅓ XI, 145., 146, 147., 148, 149..., 150, 154, 187., 231, 256., 257, 262

(요) $\mathrm{XIII}, 67,156$

(오 $\mathrm{XI}, 576,579 \ldots . ., 581,605,607 . ., 608 . ., 609 \ldots, 610 \ldots, 611 \ldots ., 612 ., 614,615 ., 616,617,618 \ldots, 619 ., 620 \ldots, 621 \ldots ., 622 ., 627$

(ज) XII, 261.

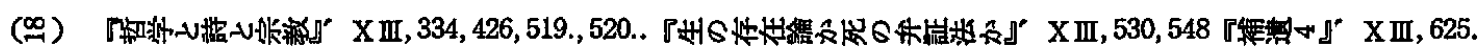

